\title{
Küreselleşme Asrında Ulusal Güvenlik Perspektifinden Medya-Güvenlik İlişkisi ve Topluma Yansımaları
}

\section{The Media-Security Relationship from the National Security Perspective in the Globalization Era and its Reflections to the Society}

\author{
Tirab Abbkar TİRAB*
}

$\ddot{O} z$

Bu çallşmada küreselleșen dünyamızda güvenlik ile medya arasindaki etkileşim irdelenmeye çallşılmış̧ır. Geçmişten günümüze insanoğlu için büyük önem arz eden güvenliğin küreselleşmeyle birlikte kapsaminda ve mefhumunda köklü değişimler yaşanmıştır. Bu değişimlere paralel olarak güvenliği sağlama strateji ve yöntemleri de değişmiştir. Zira günümüzde bir toplumda güvenliği sağlamakta sadece güvenlik birimlerinin değil, toplumu paylaşan herkesin göz ardl edilemeyecek rolü bulunmaktadır. Bu aktörlerden biri medyadır. Medya, özellikle önleyici güvenlik alanında büyük etkinliğe sahiptir. Medyanın güvenliğin sağlanmasinda öneme sahip olmasl, iki sektör arasinda bir koordinasyon ve iş birliği gerekliliğini ortaya koymaktadır. Bu doğrultuda çalışmanın temel konusu, güvenlik medyası kavraminın mahiyetini ve güvenliğin sağlamasında medyanın oynadığı rolü açıllayacak biçimde şekillendirilmiştir.

Anahtar Sözcükler: Medya, güvenlik, güvenlik medyasl, ulusal güvenlik, küreselleşme.

\section{Abstract}

This study has tried to examine the interaction between security and media in our globalizing world. There have been fundamental changes in the scope and the meaning of security with the globalization, which has been important for

\footnotetext{
* Dr, Araştırmacı, e-posta: tabbakar@hotmail.com.
}

Geliş Tarihi / Received : 23.01.2017

Kabul Tarihi / Accepted : 28.06.2017 
humanity from past to present. Parallel to these changes, the strategies and methods of ensuring security have also changed. Because in today's society, not only the security units, but also the society itself share a role which cannot be

Y11: 13 ignored in providing security. One of these actors is the media, which has a particularly high level of effectiveness in the field of preventive security. The importance of media on ensuring the security leads us to the necessity of coordination and cooperation between these two sectors. In this respect, the main theme of the study was designed to explain the nature of the security media concept and how the media plays a role in providing security.

Keywords: Media, security, media of security, national security, globalization.

\section{Giriş}

Küreselleşmenin etkisinin her alanda görüldüğ̈ ve belirgin biçimde hissedildiği bir çağda yaşamaktayı. Küreselleşmenin getirdiği imkânlar, hayatımızın her alanında farklı değişimlere yol açmıştır. Bu alanlardan biri de güvenlik alanıdır. Nitekim küreselleşme ile birlikte güvenlik kavramının tanımı, kapsamı, etki ve etkileşiminde büyük değişimlerin yaşandığı aşikârdır. Zira bugün güvenliğin sağlanması ile ilgili plan ve stratejiler belirlenirken birçok alanı göz önünde bulundurmak gerekmektedir. $\mathrm{Bu}$ kapsamda değişmeyen tek şey, güvenliğin önemidir. Bu nedenle, güvenliğin bir olgu olarak geçmişten günümüze kadar insanoğlunun temel ihtiyaçlarından biri olduğunu ifade etmek mümkündür.

Öte yandan küreselleşme ile birlikte güvenliğin diğer disiplinlerle ilişkisinde ve etkileşiminde de yeni alanlar kendini göstermiştir. $\mathrm{Bu}$ bağlamda medya göz ardı edilemeyecek bir öneme sahiptir. Öyle ki günümüzde medya ile güvenlik arasında etki-sonuç ilişkisi söz konusudur. $\mathrm{Bu}$ nedenle toplumda düşünce ve yönelimleri açısından sağlıklı bir insanın yetişmesi için medya araçlarının içerikleri belirlenirken, toplumun kültürel değerleri ve selameti ile ülkenin güvenliği göz önünde bulundurulmadır. Bunun, dolaysız olarak toplumda güvenliğin sağlanmasında olumlu etkisi olacaktır; çünkü düşünce ve yönelimleriyle sağlıklı insanlara sahip olan bir toplumda güvenlik riskinin en düşük seviyede olması beklenmektedir. Zira insan, toplumun temelidir. Temeli sağlıklı insanlardan oluşan bir toplumu paylaşan insanların 
Küreselleşme Asrında Ulusal Güvenlik Perspektifinden

Medya-Güvenlik İlişkisi ve Topluma Yansımaları

güven içinde olmaları ve istikrarlı bir yaşam sürdürebilmeleri doğaldır.

Bununla beraber, medya insanların duygu ve bilinçaltlarına hitap etmektedir. Güvenlik ise aslında bir ihsastır. İnsanın güven ve barışta olma ihsasıdır. $\mathrm{Bu}$ nedenle, bu ihsas ve duyguların medya araçlarıyla hitabının, daha etkin ve hızlı olması doğaldır. Belirtildiği üzere, günümüzün gelişen imkânları medya ve güvenliği birbirlerinden ayrılmaz parçalar haline getirmiştir. $\mathrm{Bu}$ durum ise söz konusu iki alandaki bilimsel çalışmaları birbiriyle bağlantılı kılmaktadır.

$\mathrm{Bu}$ doğrultuda, bu çalışmada güvenlik ile medya arasındaki ilişki ele alınacak ve farklı başlıklar altında değerlendirmeye çalışılacaktır. Çalışmada ele alınan konu başlıklarında yeknesaklık olması için ilk başta güvenlik kavramı ele alınarak tanımlanmıştır. Daha sonra sırasıyla güvenlik medyasının tanımı, önemi ve amaçları, güvenlik medyasının alanları, güvenlik medyasının yöntem ve araçları, medya ile güvenlik kurumları arasındaki iş birliği ve koordinasyon, güvenlik medyası ve ulusal güvenlik konularının üzerinde durulacaktır. Sonrasında ise çalışmanın sonuç bölümüne geçilecektir.

\section{Güvenlik Kavramının Tanımı ve Kapsamı}

Güvenlik, her ne kadar geçmişten günümüze kadar birçok değişime uğrasa da, asırlar boyunca insanoğlu için ehemmiyetini kaybetmemiştir. Zira güvenlik her dönemde insanoğlunun temel ihtiyaçlarından birisi olmuştur ve olmaya da devam edeceği düşünülmektedir. Güvenlik kavramı, daha önce sadece askerî, uluslararası ilişkiler ve savaş ile ilintili konuların ilgi alanı sayılırken günümüzde insanoğlunun hayatının her alanına girmiştir. ${ }^{1}$ Bu değişimin nedenleri arasında güvenlik kavramının her dönemde yaşanan gelişmeleri kapsayacak şekilde sürekli olarak dönüşümde olmasını, çağdaş yaşam koşullarına bağlı olarak meydana gelen güvenlik tehlikeleri ve ihtiyaçlarını karşılayabilmek için devamlı olarak bir yenileme evresi içerisinde olmasını ve ayrıca bilimsel ve mesleki uzmanlar tarafından

\footnotetext{
${ }^{1}$ Lucia Zedner, Güvenlik, çev. Defne Orhun, Optimist Yayın Grubu, İstanbul, 2015, s.13.
} 
Bilimsel ve mesleki uzmanlar tarafindan güvenlik ile ilgili yapılan değerlendirmeler ve bunlara bağlı olarak güvenlik kavramı üzerine medyada oluşan etkiye örnek olarak sosyologların güvenliği sosyal bir perspektiften ele almalarını, güvenliğin sağlanmasında toplumsal kurumları ve değişimleri ön planda tutmalarını; ekonomistlerin ise güvenliğe ekonomik bir bakış açısıyla bakmalarını ve güvenliğin sağlanmasında toplumda refahın vuku bulması ve kalkınmanın gerçekleştirilmesine bağlamalarını gösterebiliriz.

$\mathrm{Bu}$ denli geniş bir yelpazeyi kapsayan güvenlik kavramının tanımı hakkında günümüze kadar uluslararası olarak kabul edilen bir birlikteliğin sağlanmadığını ifade etmek mümkündür. Bu adem-i birlikteliğin arkasındaki en belirgin etken, güvenlik kavramının esnek ve bakış açısına göre şekillenebilen bir kavram olmasıdır. Bu çalışmada güvenliğe yapılan tanımlardan bazılarına yer verilecektir. Yer verilecek tanımlar, güvenliğin her alanını kapsayacak şekilde genel olmasının yanında çalışmanın temel konusunun ekseninde olacaktır.

Bu doğrultuda güvenlik ile ilgili yapılan tanımlardan biri, Arends'ın yaptığı tanımdır. Arends'a göre, İngilizcede "Security" olarak ifade edilen güvenlik kavramı, korkunun ve endişenin olmamasını ifade etmektedir. Zira "Security" sözcüğü iki şıtan oluşmaktadır. Biri "se"dir. "Se" sözcüğü, "olmamak-olmaksızın" anlamına gelmektedir. Diğeri ise "cura". "Cura" sözcüğü "endişe ve korku" anlamlarına gelmektedir. İki sözcügün birleşmesiyle, üstte adı geçen tanım ortaya çıkmaktadır. ${ }^{3}$

Diğer tanımlardan biri de Benjamin'den gelmektedir. Benjamin, güvenliği genel anlamda "tehdit, korku ve tehlikelerden uzak olmak" şeklinde tanımlamıştır. Ona göre, kişilerin veya tüzel kişilerin güvende olması iki olguya bağlıdır. İlki, bulundukları yerde kendilerine yönelik

${ }^{2}$ Tirab Abbkar Tirab, Çokkültürrlülük ve Güvenlik: Sudan Örneği, Sonçağ Yayınları. Ankara, 2016, s. 102.

${ }^{3}$ J. Frederik M. Arends, "Homeros'dan Hobbes ve Ötesine: "Güvenlik" Kavramının Avrupa Geleneğindeki Boyutları”, Uluslararası IIlişkiler, 2015, Cilt:6, 22, ss.3-33. 
herhangi bir tehlikenin söz konusu olmamasıdır. İkincisi ise tehlikenin var olması halinde söz konusu tehlikeye karşı koyabilecek bir kapasiteye sahip olmasıdır. ${ }^{4}$

Diğer bir tanım ise sözcüğün Arapça manasından esinlenerek yapılmıştır. Güvenlik sözcüğü, Arapça'da "Amn" olarak ifade edilmektedir. "Amn" sözcügü, "sükünet, korkusuzluk, istikrar, kendini tatmin, dürüstlük ve emanet" anlamlarına gelmektedir. Yani korkunun ve huzursuzluğun olmamasıdır. ${ }^{5}$

Brauch'a göre ise güvenlik, sosyal bilimlerin temel kavramlarından biridir ve bütün toplumlar için vazgeçilmez unsurlardandır. Ancak toplumda var olan bireylere, konulara, toplumsal adetlere, değişen tarihsel süreç ve şartlara bağlı olarak farklı şekillerde tanımlanabilmektedir. ${ }^{6}$ Aslında bu görüş, günümüzdeki güvenlik kavramının kapsamı ile doğrudan bağlantılıdır. Zira küreselleşmenin sunduğu imkânlar ve meydana getirdiği şartlarla uluslararası konjonktürlere bağlı olarak güvenliğe her geçen gün yeni alanlar eklenmektedir. Bu anlamda, Karabulut'a ${ }^{7}$ göre, geleneksel güvenlik anlayışında devlet ve askerî/politik konular ön plandayken; çağdaş güvenlik anlayışının temelinde birey yer alarak güvenliğe çevre, ekonomik, toplumsal, demografik, bilgi-bilişim ve teknoloji gibi yeni boyutlar kazandırılmıştır.

Çalışmanın bir önceki başlığında güvenlik kavramının kapsamı ve tanımı üzerinde durulmuştur. Bir sonraki başlıkta ise bu denli geniş kapsamlı olan güvenlik kavramında, günümüzün en etkin aktörlerinden biri olan medya ile güvenlik arasındaki ilişki irdelenecektir. Bu kapsamda medya ile güvenlik arasındaki ilişkinin terimlendirilmesi ve

\footnotetext{
${ }^{4}$ Miller Benjamin, "The Concept of Security: Should it Be Redefined" Journal of Strategic Studies, 2001, Vol. 24, No.2, p. 16.

${ }^{5}$ Tirab Abbkar Tirab, a.g.e, s.103.

${ }^{6}$ Günter Hans Brauch, "Uluslararası İlişkilerde Çatışmadan Güvenliğge, Mustafa Aydın (ed), Güvenliğin Yeniden Kavramsallaştırılması: Barış, Güvenlik, Kalkınma ve Çevre Kavramsal Dörtlüsü̈, İstanbul Bilgi Üniversitesi Yayınları, İstanbul, 2015, s. 168.

${ }^{7}$ Bilal Karabulut, Küreselleşme Sürecinde Güvenliği Yeniden Düşünmek, Barış Kitabevi, Ankara, 2011, s. 122.
} 
118

Güvenlik

Stratejileri

Y1l: 13

Sayı: 26

bu ilişkinin önemi ve amaçlarının üzerinde durulacaktır.

\section{Güvenlik Medyasının Tanımı, Önemi ve Amaçları}

Devletin yapılanmasıyla ilgili entelektüel tartışmaların çoğunda, bir ülkede demokrasinin teminatı olarak tek elde toplanmaması gereken üç güç (yasama, yürütme ve yargi) olduğundan bahsedilmektedir. Ancak medyanın siyasal ve toplumsal hayatı daha yakından etkilemesiyle "dördüncü güç" kavramı bilimsel literatürde kullanılmaya başlanmıştır. Medyanın dördüncü güç olarak adlandırılması toplumda ne denli etkili olduğunu göstermektedir. Zira günümüzde medya insanların üzerinde en etkili aktörlerden biridir. İnsanların hayata bakış perspektiflerini şekillendiren, farklı konularda nasıl düşüneceklerini belirleyen, hayat biçim ve alışkanlarında büyük rol oynayan medya organlarının bu anlamda bir bütün olarak toplumun üzerinde göz ardı edilemeyecek bir etkisi mevcuttur.

Bazı bilimsel çalışmalarda "dördüncü ordu" olarak adlandırılan medya, bütün organlarıyla (işitsel, görsel ve yazılı) 11 Eylül saldırılarından sonraki süreçte olduğu gibi toplumu topyekûn olarak istenilen yöne yönlendirebilme gücüne sahiptir. ${ }^{8}$ Medyanın toplum üzerinde bu denli bir etkiye sahip olması, toplumda güvenliğin tüm alanlarıyla sağlanması bağlamında güvenlik birimleri için medyayı kaçınılmaz kılmaktadır.

Öyle ki günümüzde medya organlarının güvenlik alanında güçlü ve etkili bir rol oynadığı aşikârdır. Zira medya organları güvenliğin akışını ve güvenlik birimlerinin etkinliğini etkileme bakımından pratikte en güçlü organlar sayılmaktadır. Genel olarak, medyanın güvenlik üzerindeki etkisi pozitif veya negatif olmak üzere iki şekilde tezahür etmektedir. Başka bir ifadeyle, günümüzde medya organlarını ve yayınlarını takip eden bir kişi, medyanın güvenliğe yönelik pozitif yönünden etkilenebileceği gibi, negatif yönünden de etkilenebilmektedir.

Örneğin geleneksel güvenlik anlayışı kapsamında çoğunlukla

\footnotetext{
${ }^{8}$ Rahmi Yıldırım, Dördüncü Ordu Medya, Karınca Yayınları, Ankara, 2010, s. 138.
} 
Küreselleşme Asrında Ulusal Güvenlik Perspektifinden

Medya-Güvenlik İlişkisi ve Topluma Yansımaları

zihinleri açan ve özellikle gençler olmak üzere bireylerin dikkatini suça çeken polisiye vakalarının olduğunu görmekteyiz. Medya organlarında bu suçların ustaca ve güvenlik birimlerinden gizlenerek özenle işlendiği gösterilir. Bu durum, bazı insanları bu suçları taklit etmeye itmekte ve bunlara karşı sempati duymalarına yol açmaktadır. Bunun sonucunda zaman zaman söz konusu filmlerden esinlenerek işlenen suç vakaları da görülebilmektedir. Bu durum, medyanın güvenliğin üzerindeki olumsuz etkisini doğrudan pekiştirmektedir. Diğer perspektiften bakıldığında ise, medyada toplumun kültürel ve ahlaki değerlerini pekiştiren, toplumun sahip olduğu tüm farklılıkları benimseyen ve eşit biçimde değerlendirildiğini gösterilen içeriklerin yayınlanması sonucunda oluşan millî birlik ve beraberlik ruhu, ülkenin toplumsal ve ulusal güvenliği açısından önem arz etmektedir. Bu durum ise medyanın güvenliğe pozitif etkisini göstermektedir.

Toplumlar üzerinde bu denli etkili olan medyanın tanımı hakkında günümüze kadar bir fikir birliği sağlanamamıştır. Bu doğrultuda konunun uzmanları, tanımdan ziyade medyanın rolünü ve toplumun farklı kısımları üzerindeki etkisini gözler önünde sererek ve muhtelif yönlerini açıklayarak medyayla ilintili genel bir kavram ortaya koyabilmiştir. Nitekim Al-Shinkheti medyanın tek bir yapısı olmadığını, yanıltıc1, doğru ve yönlendirici medya olduğunu belirtmiştir. Bundan dolayı medya için belirlenecek tanım, medyanın bütün türlerini kapsamalıdır. Bu bağlamda yazar medyayı şöyle tanımlamıştır: Medya; hakikatleri, duyguları, fikirleri veya kişisel ya da toplumsal söz yahut davranış tecrübelerini etkilemek amacıyla bireye/topluma taşımayı amaçlayan her söz veya eylemdir.

Dünya bugün medya sayesinde daha önce benzeri görünmeyen bir yöntemle bilgilerin dolaştığı küçük kapalı bir oda haline gelmiştir. Medya bir günde insanların hayatıyla ilgili milyonlarca mesaj vermekte; analiz, bilgi, görüş, davranış ve ahlaki değerler ortaya koymaktadır.

\footnotetext{
${ }^{9}$ Saeed Mohammed Sadati Al-Shinkheti, Mafahim İslamiya Min Al-Khuran Al-
} Karem, Dar Alam Al-Kitab, Riyadh: 1986, ss. 17-18. 
Konuyu güvenlik ile bağlayacak olursak, medyaya olan ilgi ve medyanın güvenlik üzerindeki önemli etkisi, reel bir gereklilik haline gelmiştir. Oysa ki uluslararası toplum, medyanın güvenlik ve savaş alanlarındaki etkisiyle Soğuk Savaş dönemiyle karşı karşıya kalmıştır. Zira Soğuk Savaş döneminde medyanın bu bağlamdaki etki boyutu tanımlanmıştır. Öyle ki bazı yazarlara göre Soğuk Savaş, medyanın silah olarak kullanıldığı bir savaştır. ${ }^{10}$

Teknolojinin gelişmesi ve insan hayatının her alanına girmesiyle birlikte, birçok sektörde değişim yaşandığ 1 gibi güvenlik ve suç kavram ve yöntemlerinde de büyük değişiklikler yaşanmıştır. İletişimin ve bilginin zirvede bulunduğu bu modern çağımızda yeni suç şekilleri ortaya çıkmıştır. Ayrıca güvenlik tehditlerine de yeni boyutlar katılmıştır. Geleneksel güvenlik anlayışında güvenliği tehdit eden faktörler daha belirgin ve basitken; günümüzde güvenlik tehditleri yazılı, görsel ve işitsel medya araçlarıyla daha da karmaşık bir hâl almıştır. Bu da insanların güvenlik endişelerini ve istikrarsızlıkla ilgili kaygılarını büyütmektedir. Üstelik güvenliğin kavram ve teorilerinde farklı boyutların öne çıkmasının yolunu da açmıştır. İşte bu bağlamda, medya ile güvenlik arasındaki etkileşim teorisi ortaya çıkmaktadır. ${ }^{11}$

Güvenlik ile medya arasındaki ilişkiyi ele alan çalışmaların azlığının yanı sıra, konuyu ele alan entelektüel tartışmaların çoğunda medya ile güvenlik arasındaki ilişkiyi ifade etmek üzere "medya güvenliği" ve "güvenlik medyası" kavramları kullanılmıştır. ${ }^{12}$ Aslında, bu iki terimin birbirleriyle bağlanarak bu biçimde kullanılması, hem güvenlik alanına yeni bir terim ve alan kazandırmış; hem de medya ile güvenlik arasındaki ilişkinin ne denli sıkı ve kaçınılmaz olduğu

${ }^{10}$ Ali Bin Fayiz Al-Jahani, Al-íelam Al-Amni va Al-Wikhaya Min Al-Jarima, Markaz Al-Buhoos va Al-Dirasat, Naif University for Security Sciences, Riyad, 2000, s. 109.

${ }^{11}$ Ali Bin Fayiz Al-Jahani, "Al-İlam Al-Amni Beyn Al-Wakhi va Al-Tataloat", AlJahani, Ali Bin Fayiz (ed.), Baramij A-Lilam Al-Amni Beyn Al-Wakhi va AtTataloat, Manshorat Naif University for Security Sciences, Riyadh, 2012, ss. 91-117.

${ }^{12}$ Baraka Bin Zamil Al-Hawshan, Al-Eilam Al-Amnni va Al-Amn Al-Eilami, Naif University for Security Sciences Yayınları, Riyadh, 2004, s. 11. 
hakkında ipucu vermiş̧ir. Yukarıda bahsedildiği üzere, güvenlik; birey, toplum ve devletler için önemli bir değer ve gerçekleştirilmesi gereken bir amaçtır. Nitekim hükümetlerin ve devletlerin gerçekleştirmeleri gereken amaç; bireylerin ve toplumların siyasi, ekonomik ve sosyal açıdan istikrarlı, verimli ve güvenli bir ortamda yaşamalarını sağlayacak psikolojik ve fiziki güvenlik sentezini oluşturmaktır. İşte bu bağlamda, devletler güvenliği tüm boyut ve alanlarılla gerçekleştirebilmek için "güvenlik medyası"na önem vermelidir.

Medya toplumun farklı alan ve sektörlerindeki gelişmeleri yansıtma konusunda ayna niteliğindedir. $\mathrm{Bu}$ nedenle, milletlerin yaşam biçimleri üzerine doğrudan ve dolaylı olarak tesir etmektedir. Zira medya geçmişte her ne kadar daha çok siyaset ve eğlence ile bağlantılı bir kavram olsa da, günümüzde iletişim sistemleri araçlarındaki gelişmeler ile birlikte insan hayatının her alanına girebilmiştir. Bunun doğal sonucu olarak, medyada her sektöre ilişkin bir birim oluşturma ihtiyacını doğurmuştur. Başka bir ifadeyle, medyada bir ihtisaslaşma sürecine girilmiş; sağlık medyası, spor medyası ve ekonomi medyası gibi farklı alanlara hitap eden medya türleri ortaya çıkmıştır. Bu sektörlerden biri de güvenlik medyasıdır.

"Güvenlik medyası" kavramına, İngiliz ve Arap literatürleri dışında, medya ile güvenlik arasındaki etki ve etkileşimi irdeleyen çalışmalarda çok rastlanmamaktadır. Ayrıca, bu terimin İngiliz literatüründen önce Arap literatüründe kullanılmaya başlandığı ifade edilmektedir. Bu nedenle, bu terimin Arap literatürünün terimi olduğunu ileri sürmek mümkündür. ${ }^{13}$ Terim, ülkenin iç ve dış güvenliği ile ilintili bir terimdir. Ayrıca toplumun kültürel ve fikri yapısının dayanağına bağlı olarak güven ve istikrarla da yakından ilgilidir. Terime yapılan tanımlarda bir birlikteliğin olmadığı görülmektedir. Bunun arkasındaki en etkin neden, terimin diğer sosyal bilimlerin terimleri gibi esnek bir terim olmasidır.

$\mathrm{Bu}$ bağlamda güvenlik medyasını, "medyadaki gelişmiş teknolojik

${ }^{13}$ Al-Hawshan, a.g.e, s. 20. 
122

Güvenlik Stratejileri

Y1l: 13

Say1: 26 imkân ve yöntemleri kullanarak toplumun kültürel ve etnik yapısı ile toplumsal değerlerini göz önünde bulundurarak ülkenin ulusal ve uluslararası güvenliği doğrultusunda, insanlara güvenlikle ilintili hak, görev ve sorumlulukları, güvenliğin sağlanmasına ilişkin bilgiler, suç ve suçluluk kavramlarına dair doğru bilgi veren, konuları ele alan medyadır" ş̧eklinde tanımlayabiliriz. Tanımdan görüleceği üzere güvenlik medyasının odağında bilgilendirme görevi bulunmaktadır. Aynı zamanda, vatandaşların güvenlik bilincini güçlendirmede de büyük görev üstlenmektedir. Aslında güvenlik medyasının diğer önemli fonksiyonu, güvenliğin herhangi bir alanda sağlanması konusunda doğrudan etkisinin olmasıdır. Örneğin; toplumun ulusal kimliğini pekiştiren konuları ele alarak toplumun "kültürel güvenliği"nin sağlanmasında rol oynayabileceği gibi, trafik kurallarını anlatan bir programla "trafik güvenliği"nin sağlanmasında da rol oynayabilmektedir.

Bilgiye ulaşma araçları değerlendirildiğinde, medyanın büyük bir önem arz ettiği görülecektir. İşte güvenlik medyasının önemi burada kendini göstermektedir. Nitekim bu denli yaygın olarak kullanılan medya araçlarının toplumun güvenlik bilincinin arttırılmasında kullanılması kaçınılmazdır. Bu, özellikle, daha iyi yaşam şartlarını arayan ve güvenlik alanında gerçek sorunlarını belirlemeye çalışan gelişmemiş toplumlarda daha önemlidir. ${ }^{14}$ Ayrıca medyanın toplum üzerindeki birleștirici gücünden hareketle güvenlik medyasının, toplumun güvenliğine ilişkin konulara daha kapsamlı bir biçimde katılmasını sağladığı ifade edilebilir. Zira günümüzde toplumlar ancak toplumun bütün ilgili kısımlarının bilimsel katkı ve çabalarıyla ortadan kaldırabileceği birçok güvenlik sorununu barındırmaktadır.

Güvenlik medyasını önemli kılan diğer özelliklerden biri de, güvenlik ile medya arasındaki bağı koruyan bir alan olmasından kaynaklanmaktadır. Zira söz konusu bu bağın ortadan kalkması, toplumu,

${ }^{14}$ Hamza Ahmed Beytalmal, "Dawr Al-İlam Alamni Fi Al-Wikhaya Min Al-Harima", Al-Jahani, Ali Bin Fayiz (ed.), Al-ílam Al-Amni va Al-Azmat, Manshorat Naif University for Security Sciences, Riyadh, 2012, ss. 251-275. 
bilgilendirme ve aydınlatma konusundaki en önemli faktörlerden birinden yoksun birakacaktır. Böyle bir durum, güvenlik ve güvenlikle ilintili konulardan uzak ve bilgisiz bir toplum oluşmasına neden olacaktır. Böyle bir toplumun endişe, psikolojik istikrarsızlık ve korkularla boğulması beklenmektedir. Bunun aksine, güvenlik medyasına önem vermek, toplumun geleneksel evreden daha çağdaş evreye geçişini sağlayacaktır. ${ }^{15}$

Küreselleşme ile birlikte toplumsal, siyasal ve ekonomik olmak üzere hayatın tüm alanlarını kapsayacak şekilde genişleyen güvenlik olgusu, ülkenin kalkınmasıyla doğrudan bir bağlantıya sahiptir. Hatta güvenlik ile kalkınma bir paranın iki yüzü gibidir. Biri olmadan diğeri eksik ve anlamsız kalır. Bu anlayıştan yola çıkarak, güvenlik medyasına önem vermeyerek bu denli önemli olan güvenlik olgusu ve güvenlik kurumlarının ehemmiyeti hakkında bilgisiz olan bir toplumun nasıl bir tehlike ile karşı karşıya olduğu anlaşılacaktır.

$\mathrm{Bu}$ çerçevede değinilmesi gereken bir diğer husus; vatandaşların desteği ve çabası olmaksızın sadece güvenlik kurumları tarafından güvenliğin sağlanamayacağ 1 ve toplumun bütün üyelerinin güvenliği sağlamaktan sorumlu olduğu gerçeğidir. Güvenlik kültürü yerleşmemiş toplumlarda güvenliği sağlama görevinin, geleneksel güvenlik anlayışında olduğu gibi, sadece güvenlik güçleri tarafından üstlenildiği düşünülmektedir. Oysa güvenliğin sağlanmasında toplumda herkesin bir görevi mevcuttur. Bu anlayışı yerleştirmek ise ancak güvenlik medyası ile gerçekleştirilebilmektedir.

Güvenlik medyasının temel amaçları şöyledir:

1. Vatandaşları bilgilendirmek ve aydınlatmak amaciyla kampanyalarla toplumda istikrar ve güvenliğin önemi hakkında sosyal farkındalığ 1 geliştirmektir.

2. Vatandaşlara, hayatlarının şimdiki hâlini ve geleceğini ilgilendiren güvenlik konuları hakkında gerekli bilgiler

\footnotetext{
${ }^{15}$ Ahmed Abdülaziz Al-Asfar, Asbab Taati Al-Mukhatdirat Fi Al-Mojtama Al-Arabi,
} Markaz Al-Buhoos va Al-Dirasat, Naif University for Security Sciences, Riyadh, 2012, s. 85. 
124

Güvenlik Stratejileri

Y1l: 13

Say1: 26

sunmaktır. Zira bu bilgilerin olmaması, insanların söylenti ve dedikodulara yönelmelerine neden olacaktır. Ya da insanlar güvenlik birimleri dışında tamamen asılsız doğru olmayan bilgilere itimat edecektir.

3. Güvenlik birimleri ile vatandaşlar arasındaki ilişkileri güçlendirmektedir. Çünkü güvenliği sağlamada vatandaşların gösterdiği çaba güvenlik birimlerinin çabasını tamamlamaktadır.

4. Güvenlik personeline kendi alanlarında yaşanan gelişmeleri yakından takip etme imkânı sunmaktır. Zira günümüzde güvenlik alanında hızlı bir gelişme söz konusudur. $\mathrm{Bu}$ gelişmelerden uzak bir güvenlik personelinin görevinde başarılı olma ihtimali düşüktür.

5. Yeni yöntemlerle işlenen suçlar hakkında vatandaşlara bilgi vererek aynı yöntemlerle söz konusu suçun kurbanları olmalarını engellemektir. ${ }^{16}$

Yukarıda bahsedildiği üzere, medya ile güvenlik arasındaki bağa ilişkin olarak kullanılan bir diğer kavram, "medya güvenliğì" kavramıdır. Kavram, medya programlarının içerikleriyle ilgili bir kavramdır. Düşünce ve özgürlük ilkeleri çerçevesinde medyada ele alınan konuların ülkenin ve toplumun güvenliği ile arasındaki paradoksallığı önlemeye çalışmaktadır. Devletler medyanın özgürlüğünü güvence altına almak için kanunlar çıkardığ 1 gibi medyanın toplumun kültürel, toplumsal ve ahlaki değerleri ile bağdaşmayan içeriklerin yayınlamasını olabildiğince engellemeye çalışmaktadır. $\mathrm{Bu}$ engelleme iki şekilde gerçekleştirilir: Birincisi, medya organlarında çalışanların bahse konu olan konuyla ilişkin olarak eğitilmesidir. İkincisi güvenlik medyasının ve medyanın ülke güvenliğindeki önemine ilişkin farkındalık

${ }^{16}$ Abdulrahman Bin Mohammed Asiri, "Maham Al-İlam Al-Amni va vazaifaho Fi AlMujtamaat Al-Arabiya Al-Muasira", Khaddoor, Adeeb (ed.), Al-ilam va Al-Amn, Markaz Al-Buhoos va Al-Dirasat, Naif University for Security Sciences, Riyadh, 2006, s. 30. 
Küreselleşme Asrında Ulusal Güvenlik Perspektifinden

Medya-Güvenlik İlişkisi ve Topluma Yansımaları

oluşturulmasıdır. ${ }^{17}$

Ayrıca güvenliği sağlamak için medya ile devletin diğer kurumları arasında bir koordinasyon ve iş birliği mekanizması oluşturulabilir; çünkü bu konudaki yeknesak durum güvenliğin sağlanmasında büyük önem arz etmektedir.

Güvenlik medyasının tanımı, önemi ve amaçlarını irdeledikten sonra çalışmanın bir sonraki başlığında güvenlik medyasının alanları ve bu alanlarda nasıl bir etkisi ve rolü olduğu üzerinde durulacaktır.

\section{Güvenlik Medyasının Alanları}

Günümüzde medyanın yazılı, işitsel ve görsel organlarıyla sınır tanımaksızın insan hayatının her alanına girebildiği üstte bahsedilmiştir. Güvenlik ile medya arasındaki etkileşimin sınırları geniş ve esnektir. Zira güvenlik alanları ne denli geniş ve kapsamlı ise, güvenlik medyasının alanları da o denli kapsamlı ve geniştir. Ancak çalışmanın bu kısmında tüm alanının değil; güvenlik medyasının en önemli görülen ve toplumların güvenliğini tehdit etme seviyesine göre bazı alanları ele alınacaktır. Bu bağlamda, güvenliği sağlamada en önemli husus, güvenlik tehlikesi vuku bulmadan bertaraf etmektir. Buradan hareketle, çalışmanın bu kısmında güvenlik medyasının önleyici güvenlik alanındaki etkisi ve rolü incelenecektir.

\subsection{Güvenlik Medyasının Önleyici Güvenliğe Etkisi}

Önleyici güvenlik kavramı, güvenliği tehdit eden olguların vuku bulmadan önce önlenmeleri ile ilgili bir kavramdır. Güvenliği tehdit eden bir olguyu önlemek için en etkin yöntem, söz konusu olgunun daha oluşma sürecinde engellemesidir. ${ }^{18}$ Burada insanların düşünce, zihin ve duygularına kolayca hitap etmesinden dolayı, medya güvenlik güçlerinden daha etkin bir role sahiptir. Zira güvenlik güçlerinin suçun oluştuğu ortama hitap etmesinde güçlükler mevcuttur. Özellikle

\footnotetext{
${ }^{17}$ Ali Bin Fayiz Al-Jahani, 2012, a.g.e, ss. 91-117.

${ }^{18}$ İbrahim Bin Ahmed Al-Shammasi, "Al-Sakhafa Al-Amniya", Al-Khamdi Abdülaziz (ed.), Al-ilam va Asaraho Fi Al-Wikhaya Min Al-Jarima Beyn Al-İjab Va Al-Salb Manshorat Naif University for Security Sciences, Riyadh, 2003, ss. 173-220.
}

Güvenlik Stratejileri Y11: 13

Say1: 26 
126

Güvenlik

Stratejileri

Y11: 13

Say1: 26

düşünce aşamasında olan güvenliği tehdit eden eylemlerde medyanın gücü tartışılmaz. Medya ayrıca mekân ve zaman sınırları tanımaksızın bireylerin özel hayatlarına girebileceğinden, bu anlamda güvenlik güçlerinden daha etkindir.

Bu kapsamda, medyanın bu büyük toplumsal etkileme gücü, ülkenin istikrarı ve güvenli bir toplum oluşturmak için kullanılmalıdır. Böylece bireylerin ve toplumun temel ihtiyac1 olan güvenliğin sağlanmasında medyanın da katkısı sağlanmış olacaktır. Ayrıca medya, güvenliğin önemi ve güvenliği sağlamada toplumda bulunan herkesin bir görevi ve rolü olduğu hakkında toplumsal bilinç oluşturmada kullanılmalıdır. ${ }^{19}$

Böyle bir toplumsal bilincin oluşması, önleyici güvenlik anlayışında büyük önem arz etmektedir. Zira güvenlik birimlerin güvenliği sağlamada başarı göstermesi, sadece sahip olduğu imkânlara ve sayılarına bağlı değildir. Vatandaşlarla ve ülkede ikamet eden yabancilarla oluşturulacak olan iş birliği ve yardımlaşma ruhu da bu konuda çok önemlidir. Toplumun güvenlik birimlerine karşı duruşunun veya önyargısının güvenlik birimlerinin toplumu suçtan arındırmada başarılı olmasında göz ardı edilemeyecek bir etkisi mevcuttur. Zira bu birimler hakkında oluşacak olumsuz genel toplumsal algı toplumda suçların yaygınlaşmasına neden olabilecektir. Böyle bir durumda, önleyici güvenlik bir yana toplumun istikrarından bahsetmek mümkün olmayabilir. Bu nedenle, toplumda önleyici güvenliğin gerçekleştirilmesi için medya organları kullanılmalıdır.

Güvenlik medyasının alanlarından biri olan önleyici güvenliğin üzerinde durduktan sonra çalışmanın bir sonraki bölümünde bir diğer alan olan düşünce güvenliği irdelenmeye çalışılacaktır.

${ }^{19}$ Mohammed Abdulfattah Menji, “Al-Takhtet Fi Majal Al-Amn”, Murad Faruk (ed.), Al-Takhtyet Al-Amni, Markaz Al-Buhoos va Al-Dirasat, Naif University for Security Sciences, Riyadh, 993, s. 20. 
Küreselleşme Asrında Ulusal Güvenlik Perspektifinden

Medya-Güvenlik İlişkisi ve Topluma Yansımaları

\subsection{Güvenlik Medyası ve Düşünce Güvenliği}

Tüm suç ve eylemlerin ilk aşaması ve temeli düşüncedir. Kişi herhangi bir suçu veya güvenliği tehdit eden bir eylemi gerçekleştirmeden önce onu düşünür, planlar ve daha sonra gerçekleştirir. ${ }^{20}$ İşte kişilerin düşünceleriyle ilgili bir kavram olan düşünce güvenliğinin önemi düşünce biçimleriyle bağlantılı olduğundan, buna hitap eden medya ile yakından ilgilidir. ${ }^{21}$ Medya ile güvenlik sorumluları arasındaki koordinasyon ve iş birliği kapsamında planlanan programlar çerçevesinde, insanların fikri sapmaları ve suça dönük düşünmelerini engellemeye çalışan güvenlik medyası bu anlamda kaçınılmazdır.

$\mathrm{Bu}$ bağlamda belirtilebilir ki, medya suçla düşünce aşamasında mücadele ederken; güvenlik birimleri suçla maddi aşamada mücadele etmektedir. Güvenlik anlayışının temelinde suçu işlemeden engellemek asıl olduğundan, burada güvenlik medyasının düşünce güvenliğindeki rolü büyük önem taşımaktadır. $\mathrm{Bu}$ ise toplumda güvenliği sağlamak için iki sektör arasındaki iş birliği ve koordinasyonu zorunlu kılmaktadır. İş birliğinin ve koordinasyonun verimli olabilmesi için vatandaşların medya organlarında ele alınan ilgili konulara güvenmesi sağlanmalıdır. $\mathrm{Bu}$ güveni sağlayabilmek için programların içerikleri, toplumun kültürel ve toplumsal değerleri arasında paradoksal bir durum olmamalıdır. ${ }^{22}$ Ayrıca diğer ilgili tüm kurumlar ile medya arasında ülkenin "kapsamlı stratejisi" (overall strategy) çerçevesinde bir koordinasyon ve iş birliği sağlanması bu konuda önem arz etmektedir.

Güvenlik medyasının düşünce güvenliğine etkisini irdeledikten sonra, çalışmanın bir sonraki başlığında günümüzün önemli olgularından biri olan çokkültürlülüğü ve ona bağlı olarak kültürel güvenlik ile

${ }^{20}$ Ahmed Al-Ribaya, Asar Al-Sakhafa Va Al-Mujtama Fi Daf Al-Fard İla Irtikan AlJarima, Al-Markaz Al-Arabi Lildirasat Al-Amniya va Al- Tadrib, Riyadh, 1984, s. 22.

${ }^{21}$ Mohamed Al-Habib Hariz, "Wakhai Al-amn Al-fikri", Al-Liwehakh Abdulrahman, (ed.), Al-Amn Al-Fikri, Manshorat Naif University for Security Sciences, Riyadh, 2005, 77-103, s. 95.

${ }^{22}$ Mohamed Al-Habib Hariz, a.g.e., s. 82. 
128

Güvenlik Stratejileri

Y11: 13

Say1: 26

güvenlik medyası arasındaki etkileşiminin üzerinde durulacaktır.

\subsection{Güvenlik Medyası, Toplum ve Kültü̈rel Güvenlik}

Günümüzün gelişmiş imkânları, medyanın toplumsal etkilerinin geçmiş yıllara göre çok daha tesirli ve yoğun olmasına neden olmuştur. Medya, sunduğu yoğun programların içerikleriyle, insanların birçok olaya bakış açısını ve algısını kolayca yönlendirmekte ve şekillendirmektedir. Bahsi geçen bağlamda, medya; insanların kültürün temel taşları olan kültürel kimlik ve kültürel çeşitliliğe bakışını, cinsiyet ayrımını, ırk, millet gibi konular hakkındaki bakış açısını da şekillendirmektedir. Küreselleşmenin teknoloji alanındaki sunduğu imkânlarla birlikte, medyanın görsel ve işitsel araçlarında büyük gelişmeler yaşanmıştır. Günümüzde bir insan oturduğu yerden dünyanın bir diğer ucunda olan bitenler hakkında anında bilgiye sahip olabilmektedir. Örneğin; Afrika'nın bir köşesinde yaşayan bir kişi televizyon karşısında oturarak yemek ve kültür programı izleyerek Uzak Doğu'daki Çin mutfağı ve kültürü hakkında bilgi sahibi olabilmektedir. Ya da izlediği bir Hollywood filmi ile Amerikan toplumu hakkında birçok kültürel özellikten haberdar olabilmekte ve söz konusu kültüre 1 lımlı yaklaşabilmektedir. ${ }^{23}$

Günümüzde medyanın etkisi o kadar büyük bir hâle gelmiştir ki, medya aracılığıyla insanların birçok konu hakkında nasıl düşüneceklerini, hangi konuya olumlu veya olumsuz yaklaşmaları gerektiği belirlenebilmektedir. ${ }^{24}$ İnsan hayatının her aşamasında etkili olan medya, çok kültürlülük perspektifinden ele alındığında iki boyut ortaya çıkmaktadır. Birinci boyut, çok kültürlülüğü destekleyen söylem ve içerikler sunarak çok kültürlülüğe karşı olumlu tutum ve izlenimler geliştiren boyuttur. ${ }^{25}$ İkinci boyut ise çok kültürlülüğe ve kültürel

${ }^{23}$ Carlos E. Cortes, "Using Media To Support Multiculturalism”, http://www.intime. uni.edu/multiculture/Media/media.htm (Erişim Tarihi: 07 Ekim 2010).

24 Julia Petrozza, "Critical Multicultural Education and the Media", http://www.edchange.org/multicultural/papers/media.html (Erişim Tarihi: 06 Ekim 2015).

${ }^{25}$ Douglas Kellner, "Cultural Studies, Multiculturalism, and Media Culture", https://pages.gseis.ucla.edu/faculty/kellner/essays/culturalstudiesmulticulturalism.pdf, 
Küreselleşme Asrında Ulusal Güvenlik Perspektifinden

Medya-Güvenlik İlişkisi ve Topluma Yansımaları

çeşitliliğe karşı içeriklerle toplumda kültürler arasındaki hoşgörü ve saygiyı ortadan kaldıran boyuttur. ${ }^{26}$

İşte güvenlik medyasının önemi burada ortaya çıkmaktadır. Ülkenin sahip olduğu tüm etnik grupları ve kültürel değerleri arasında çatışmalara mahal vermeden yaşatabilmek için ülkenin kültürel ve toplumsal güvenliğinden sorumlu güvenlik birimleri ile medya arasinda sıkı bir koordinasyon ve iş birliği geliştirilmelidir. Güvenlik medyasının programlarıla toplumu oluşturan insanların bilinçaltlarında, istisna olmaksızın toplumun barındırdığı bütün kültürler eşit ve hepsinin devlet, ülke ve toplum için zenginlik olduğu düşüncesi yerleştirilmelidir. Böyle bir atmosfer oluşturulduğunda, ülkenin toplumsal ve kültürel güvenliğine karşı herhangi bir tehdit söz konusu olmaz. Aksi takdirde, yani medya organlarında ele alınan konuların içerikleri toplumun kültürel yapısı ile bağdaşmadığında ya da toplumda bölünmelere ve ayrışmalara yol açan nitelikte olduğunda, toplumda yaşanacak kültürel çatışmalar, ülkenin toplumsal ve kültürel güvenliğini tehdit altında birakacaktır. $^{27}$

Güvenlik medyası ile toplumsal ve kültürel güvenlik arasındaki etkileşim tartışıldıktan sonra, çalışmanın bir sonraki başlığında güvenlik krizlerinde güvenlik medyasının rolü irdelenecektir.

\subsection{Güvenlik Medyası ve Güvenlik Krizleri}

Kriz kavramı son zamanlarda farklı disiplinlerde farklı tanım ve anlamlarla sıkça kullanılmaya başlanmış bir kavramdır. Alıșılan durumun dışında ek olarak fazla çaba gerektiren süreçler, kriz olarak adlandırılabilir. Krizler farklı alan ve kurumlarda yaşanabileceği gibi, güvenlik alanında ve güvenlik kurumlarında da yaşanabilir ve yaşanmaktadır. Ancak güvenlik sektörü diğer sektörlerden farklı olduğundan, bu alanda meydana gelen krizler de diğer krizlerden farklıdır. Zira güvenlik krizleri daha kapsamlı olup diğer kurumsal

(Erişim Tarihi: 06 Ekim 2015).

${ }^{26}$ Tirab Abbkar Tirab, a.g.e, s. 68.

${ }^{27}$ Ali Bin Fayiz Al-Jahani, 2000 a.g.e., s. 219. 
krizlerden farklı olarak daha geniş bir kitle ve yelpazeyi ilgilendirmektedir. Ayrıca, bir ülkede güvenlik ile ilgili yaşanan krizler ulusal ve uluslararası medya organlarının ilgisini çektiği gibi, sadece yaşandığı ülke değil; bölgede ve uluslararası arenada birden fazla ülkeye de etki edecektir. ${ }^{28}$ Bununla birlikte, güvenlik krizleri durumunda sadece güvenlik kurumları değil, sağlık kurumları gibi birçok kurum devreye girecek ve dolayısıyla kriz diğer krizlerden ayrı olarak farklı bir nitelik kazanacaktır.

Medyanın insan hayatının her alanında etki gösterdiği çağımızda, farklı özellik ve boyutlara sahip olan güvenlik krizlerini yönetmek için ilgili güvenlik kurumların bünyesinde kriz zamanlarında müdahale etmek üzere medya ile koordinasyonu yürütebilecek birimlerin yapılandırılması büyük önem arz etmektedir. ${ }^{29}$ Nitekim bu birimlerin varlığı, ilgili kurumların kriz dönemlerinde müdahale etme kabiliyet ve imkânını yükseltecektir. Krizler sürekli olarak belirli aralıklarla meydana gelmediğinden oluşturulacak söz konusu birimlerde düzenlenecek eğitimler, uzmanlaşma imkânı vererek farklı krizlere kolayca müdahale etme gücünü sağlayacaktır.

Diğer taraftan özellikle güvenlik krizleri dönemlerinde vatandaşların yardımı ve krizle mücadele eden güvenlik birimlerinin gösterdiği çabaya karşı tutum ve algıları muazzam bir önem arz etmektedir. $\mathrm{Bu}$ durum, özellikle de bilgiye ulaşma konusunda da geçerlidir. Zira kriz yönetimi biliminde en önemli hususun, krize ilişkin bilgiye ulaşmak ile doğru ve sağlıklı bir bilgi akışı olduğu ifade edilmektedir. Aksi takdirde kriz sürecinden çıkma süresi uzayacak ve dolayısıyla kriz yönetilmez bir hâl alacak ve ağır sonuçlara yol açacaktır. Böyle bir durumda, özellikle güvenlik krizlerinde güvenlik

${ }^{28}$ Beytalmal Hamza Ahmed, "Dawr Al-İlam Alamni Fi Al-Wikhaya Min Al-Harima", Al-Jahani, Ali Bin Fayiz (ed.), Al-İlam Al-Amni va Al-Azmat, Manshorat Naif University for Security Sciences, Riyadh, 2012, 251-275, s. 253.

${ }^{29}$ Khaddoor Adeeb, Al-ilam Va Al-Amn, Naif University for Security Sciences, Riyadh, 1999, s. 67. 
Küreselleşme Asrında Ulusal Güvenlik Perspektifinden

Medya-Güvenlik İlişkisi ve Topluma Yansımaları

birimleri hakkında olumsuz bir alg1 oluşacaktır. İşte güvenlik medyasının güvenlik krizlerinin önlenmesindeki önemi burada tezahür etmektedir. Zira güvenlik medyasının temel amaçlarından biri güvenliğin önemine ilişkin bilinci yükselterek kriz dönemlerinde Güvenlik Stratejileri vatandaşların güvenlik birimleriyle iş birliği içerisinde olmaları için uygun bir zemin hazırlamaktır. ${ }^{30}$

Bilindiği üzere kriz yönetimi üç evreden oluşmaktadır: Bu evreler kriz öncesi, kriz esnası ve kriz sonrasıdır. Krizin önlenmesindeki en önemli evre, kriz öncesi evredir. Zira kriz kendiliğinden veya aniden ortaya çıkan bir olgu değildir. Kriz birçok faktör, neden ve etmenin etkisiyle meydana gelmektedir. Öyleyse, güvenlik krizlerini önlemek için güvenlik medyasının krize neden olabilecek faktörlerini ortadan kaldırmak amacıyla çalışmalar yürütülmesi elzemdir. Üstelik güvenlik krizleri sürecinde sağlıklı kararların alınması ve muhtemel bir krizi önleyici etkin tedbirlerin alınması için güvenlik medyası açısından kriz öncesi evre önem taşımaktadır.

Çalışmanın bu başlı̆ğında güvenlik krizleri ve güvenlik medyası arasındaki etkileşimi irdeledikten sonra, bir sonraki başlıkta güvenlik medyası ile trafik güvenliği ve bilinci konusuna değinilecektir.

\subsection{Güvenlik Medyası, Trafik Bilinç ve Güvenliği}

Konu ile ilgili ulusal ve uluslararası örgüt ve kuruluşlarınca trafikle alakalı yıllık raporlarda trafik kazalarında yüz binlerce insanın hayatını kaybettiği ifade edilmektedir. Bunun yanı sıra, yaralananların sayısının ise çok daha fazla olduğu belirtilmektedir. Bu bağlamda, ülkelerin trafik kazalarını önlemek için farklı çabalar gösterdiği ve yaşanan trafik kazalarının nedenleri arasında insan hatasının büyük bir payı olduğu bilinmektedir. Dolayısıyla, insanların trafik kurallarına sayg1 göstererek hem kendisinin, hem diğer insanların hayatlarını tehlikeye sokmamak adına bu konuda bilinçlendirilmesi büyük önem arz etmektedir.

30 Saeed Bin Ali Al-Shahrany, İdarat Amaliyat Al-Azmaat Al-Amniya, Naif University for Security Sciences, Riyadh, 2005, s. 36. 
132

Güvenlik Stratejileri

Y1l: 13

Sayı: 26

Bütün ülkelerin trafik kazalarını önlemek için kanuni yaptırımlar uyguladığı aşikârdır. Ancak söz konusu yaptırımlar kazaları tamamıyla engelleyemeyeceğinden dolayı, ilgili birimler tarafindan toplumsal bir farkındalık oluşturma yollarına girilmiştir. Zira bu farkındalık sayesinde oluşturulacak bilinçli toplumda kazaların azalması beklenebilir. Diğer yandan, özellikle çocukların küçük yaşlardan itibaren trafikle ilgili sahip olacakları bilgiler, ilerleyen dönemlerde daha bilinçli birer birey olmalarını sağlayacaktır; çünkü küçük yaşta öğrenilen bilgiler hem akılda daha uzun süre kalır, hem de bireyin kişiliğinin şekillenmesinde büyük etki eder.

Bu bağlamda, trafik kazalarını önlemek için ilgili birimler, güvenlik medyasını kullanarak Millî Eğitim Bakanlığı, medya organları ve sivil toplum kuruluşları gibi kurumlarla iş birliği ve koordinasyon kurmak suretiyle toplumda trafikle ilgili tüm boyutları kapsayan bilinçlendirme kampanyaları sürekli olarak yürütülebilir. ${ }^{31}$

Çalışmanın bu başlığında güvenlik medyasının trafik güvenliğinde nasıl kullanılabileceği tartışılmıştır. Bir sonraki başlıkta ise günümüzün en büyük toplumsal afetlerinden biri olan uyuşturucu ile mücadelede güvenlik medyasının rolü irdelenecektir.

\subsection{Güvenlik Medyası ve Uyuşturucu ile Mücadele}

Uyuşturucu, günümüzde gençlere yönelik en büyük toplumsal tehlikedir. Toplumlarda hızlı biçimde yayılmakta olan uyuşturucu kullanımı, gençlerin akıl, vücut ve genel sağlığında çok büyük zararlara yol açmaktadır. Bilhassa, işsizlik veya farklı nedenlerle toplumdan dışlanan gençlerde sık görülen uyuşturucu kullanımı, kullanıcılarda özgüven eksikliği, mutsuzluk ve hayatı kabullenmemek gibi olgulara yol açmaktadır. Bilindiği gibi, gençler her toplumda en önemli yaş grubudur. Zira söz konusu süreçte sahip olunan fiziksel ve psikolojik özellikler diğer yaş gruplarına nazaran gençleri daha verimli kılmaktadır.

${ }^{31}$ Mahmud İman Abdulrahman Ahmed, Dawr Al-ízaa Fi Nashr Al-Tawiya AlAmnniya: Al-Izaa Al-Sudaniya Anmuzacan, Manshorat Naif University for Security Sciences, Riyadh, 2010, s. 38. 
Küreselleşme Asrında Ulusal Güvenlik Perspektifinden

Medya-Güvenlik İlişkisi ve Topluma Yansımaları

Al-Asfar'a ${ }^{32}$ göre, gençleri uyuşturucudan korumaya verilen bu önem, devletlerin uyuşturucu ile mücadelede çok büyük çaba sarf etmelerine neden olmuştur. Buna istinaden, günümüzde tüm ülkelerin güvenlik birimlerinde uyuşturucu ile mücadele eden bir alt birim bulunmaktadır. Sözü geçen birimler uyuşturucu ile mücadelede kanuni mücadelenin yani uyuşturucu kullananlara ve ticaretini yapanlara kanuni yaptırımlar uygulamanın yanı sıra, uyuşturucu ile mücadelede önleyici faaliyetler de yürütmektedir.

İşte güvenlik medyasının önemi, bu önleme faaliyetlerinde öne çıkmaktadır. Nitekim bireyi, aileyi ve bütün olarak toplumu uyuşturucunun riski ve toplumsal sonuçları hakkında bilinçlendirmenin uyuşturucu ile mücadelede olumlu neticelere neden olacağ düşünülmektedir. Özellikle aile bu bağlamda büyük önem arz etmektedir; çünkü aile bireyin yetiştirildiği, kişiliğinin şekillendiği, doğru ve yanlışı öğrendiği yerdir ve toplumun temel taşıdır. ${ }^{33}$ Diğer taraftan, uyuşturucu ile mücadelede sadece güvenlik birimleri değil; aynı zamanda sivil toplum kuruluşları, Sağlık ve Millî Eğitim gibi bakanlıklar ve en önemlisi medya da yer almaktadır. Dolayısıyla adı geçen kurumlar arasında oluşturulacak iş birliği ve koordinasyonun platformu önem arz etmektedir.

Çalışmanın bu kısmında güvenlik medyasının uyuşturucu ile mücadeledeki rolü ve önemi irdelenmiştir. Bir sonraki başlıkta ekonomi güvenliğine etkisi tartışlacaktır.

\subsection{Güvenlik Medyası ve Ekonomi Güvenliği}

Yukarıda zikredildiği üzere, güvenlik ile kalkınma arasında güçlü bir bağlantı söz konusudur. Güvenliğin olmadığ 1 bir yerde ne kalkınmadan, ne de ekonomik gelişmeden bahsetmek mümkün olabilir. Diğer bir perspektiften bakıldığında, gelişmemişliğin ve ekonomik sorunların gölgesi altında ne bireysel ve toplumsal güvenliğin, ne de ulusal güvenliğin sağlanmasından bahsedilebilir. $\mathrm{Bu}$ kapsamda, devletin güvenliğinin, yine devletin sahip olduğu ekonomik güce ve güvenliğe

\footnotetext{
${ }^{32}$ Ahmed Abdülaziz Al-Asfar, a.g.e., s. 90.

${ }^{33}$ Ahmed Abdülaziz Al-Asfar, a.g.e, s. 152.
}

Güvenlik Stratejileri

Y11: 13

Sayı: 26 
134

Güvenlik Stratejileri

Y11: 13

Sayı: 26 bağlı olduğu ileri sürülebilir. Ayrıca halkın bu konuda bilinçlendirilmesi büyük önem arz etmektedir. Öyleyse güvenlik medyasının ekonomik bilinçlendirmeyle ilgili göndereceği mesajlar bu konuda önemli rol oynayabilmektedir. ${ }^{34}$

Nitekim Al-Zibin'in ${ }^{35}$ ifadesine göre, dolandırıcılık, kaçakçılık ve kara para aklama gibi ekonomik suçların ülke ekonomisine verdiği zarar büyüktür. Dolayısıyla bu suçların ülkenin ulusal, toplumsal ve ekonomik güvenliğine yansımaları hakkında toplumun yeterince bilinçlendirilmesinin, söz konusu suçların önlenmesinde ve mücadelesinde olumlu etki yaratacağı aşikârdır. Bu bağlamda, güvenlik medyasının ülke ekonomisinde göz ardı edilemeyecek bir rolü olduğunu ifade etmek mümkündür.

Çalışmanın bu konu başlığında güvenlik medyasının alanlarından birkaçı ele alınarak irdelenmiştir. Bir sonraki başlıkta ise güvenlik medyasının yöntem ve araçları ele alınacaktır. Bu kapsamda basın, radyo, televizyon, internet ve arama operatörleri olmak üzere beş araç ele alınarak irdelenecektir.

\section{Güvenlik Medyasının Yöntem ve Araçları}

Medya, tüm araçlarıyla güvenlik medyasının temel omurgasını oluşturmaktadır. Güvenlik medyası ise medyanın ayrılmaz parçasıdır. Güvenlik medyasının mesajları topluma ulaştırılmak istenildiğinde, medyanın yazıll, işitsel ve görsel araçlarının yanı sıra, günümüzün gelişen teknolojisinin sunduğu diğer imkânlar da kullanılmaktadır. $\mathrm{Bu}$ konuda güvenlik medyasının kullandığı araçlar ve bu araçları kullanırken başvurduğu yöntemlerden bazıları aşağıdaki gibidir.

${ }^{34}$ Sayd Shorbaci Abdulmawla, Tasir Al-Carima Ala Kutat Al-Tanmiya Al-İctimaiya, Dar Al-Nashr Bil Markaz Al-Arabi Lil-Dirasat Al-Amnniya ve Al-Tadrib, Riyadh, 1994, s. 89.

${ }^{35}$ İbrahim Mohammed Al-Zibin, "Al-Asar Al-İktisadiya Al-Natija An Zahirat AlNashl”, Al-Tarawna Mohamed (ed.), Zahirat Al-Nashl va Asariha Al-Ijtimaiya, Manshorat Naif University for Security Sciences, Riyadh, 2009, 113-156, s. 146. 
Küreselleşme Asrında Ulusal Güvenlik Perspektifinden

Medya-Güvenlik İlişkisi ve Topluma Yansımaları

\subsection{Basın (Yazıll Medya)}

Yazılı medya, okur-yazar toplum kitlesi için önemli bir haber kaynağıdır. Topluma etkisinden dolayı dördüncü güç olarak ifade edilen yazılı medya, toplumda sorunların kaynağını belirler ve vatandaşları gerekli şekilde bilinçlendirme görevini üstlenir. Bu bağlamda, ilgili birim ve kurumların söz konusu sorunlara karşı önlemlerini alması hususunda adeta bir baskı grubu rolünü üstlenmektedir. Yazılı medya, bilgiyi ulaştırmada elverişli bir araçtır. Belirli konularda okuyucuları bilinçlendirme ve aydınlatmada kullanılan en güçlü medya araçlarından biridir.

Güvenlikle ilintili olgular toplumun her kısmını ilgilendirdiğinden, bu konudaki bilgi akışı daha yoğun ve hızlıdır. Bu nedenle, toplumda yaşanan güvenlik sorunlarının önüne geçebilmek için yazılı medya organları ile güvenlik medyası birimleri arasında koordinasyon kurmak büyük önem arz etmektedir. Bu güvenlik sorunları, özellikle ülkenin ulusal güvenliğini tehdit eden konulardır. Diğer taraftan, önleyici güvenlik anlamında da yazılı medyanın katkısını sağlamak amacıyla farklı yöntemler kullanılmaktadır ve kullanılmalıdır. Örneğin; güvenlik konusu ile ilgili köşe yazıları yazılıp değişik gazetelerde yayınlanabilir. Diğer taraftan güvenlik birimleri güvenliğe ilişkin toplumsal bir bilinç oluşturmak amacıyla dergi ve gazeteler yayımlayabilir. Yayımlanacak dergi veya gazetelerin toplumu güvenlik konusunda yeterli bilinç seviyesine ulaştırabilmesi için periyodik olarak bilgi akışı sağlanmalıdır. Nitekim günümüzde birçok ülkede güvenlik medyası kapsamında güvenlik bilincini yaymak ve güvenlik sorunlarını çözmek amacıyla güvenlik birimleri tarafından çıkartılan sayısız gazete ve dergi vardır.

\subsection{Radyo}

Radyo, okur-yazarlığı olmayan insanlara da hitap ettiği için çok geniş bir toplumsal kitleyi kapsamaktadır. Ayrıca radyo her yerde kullanılabileceğinden dolayı da, bilgiye ulaşmada en etkin medya aracıdır. Zira bugün evde veya yolda araba kullanırken radyo aracılığıyla haber alınabilir. Hatta günümüzde cep telefonu cihazlarında da radyo mevcuttur. Sadece bir düğmeye basarak dünyanın her tarafindan bilgiye sahip olunabilmektedir. Tüm bu özellikler, radyoyu bilgiye ulaşmada 

dünyanın en çok kullanılan ve başvurulan medya aracı yapmaktadır. Nitekim eğitimli ve eğitimsiz insanların sınırsız olarak rahatça kullanabileceği ve önemli bir etki gücüne sahip olan bir bilgi kaynağıdır. $\mathrm{Bu}$ bağlamda, bu denli yaygın olan radyo, güvenlik medyası açısından büyük önem arz etmektedir. ${ }^{36}$ Radyoyu kullanarak toplumda geniş bir yelpazeye güvenlikle ilintili bilgiler sunarak toplumun güvenlik bilinci yükseltebilir.

Araba kullanan kişiye trafik güvenliği bilinci; çiftçiye veya fabrika işçisine yapmakta olduğu işin ülkenin ülke güvenliği için önemi; ev işleriyle uğraşan ev hanımına gösterdiği fedakârlığın ülkenin toplumsal güvenliği açısından önemi hakkında bilgiler sunarak toplumun tüm bölümlerinin güvenlik hakkındaki bilinci arttırılabilir. Tüm bu hususlar radyoda sunulacak olan güvenlik medyası programlarılla gerçekleştirilebilir. ${ }^{37}$ Radyo aracıyla uygulanan güvenlik medyası programları, özellikle ülkenin milli güvenliğini ilgilendiren konularda etkin bir role sahiptir. Zira gönderilen mesajlarla vatandaşların birlik, beraberlik ve dayanışması sağlanmaktadır. Görüldüğü üzere, radyo, güvenlik medyasının en önemli ve yaygın araçlarından biri niteliğindedir. Bunun arkasındaki en büyük neden, kapsadığı coğrafi alan ve ulaştı̆̆ geniş kitledir.

\subsection{Televizyon}

Televizyonlar, günümüzde insanların karşısında en fazla oturduğu ve zaman geçirdiği medya araçlarından biridir. Hızlı etkileme gücüne sahip olan bu bilgi alma mekanizması, insanların görme ve işitme duygularına hitap ettiğinden dolayı, medya araçları arasından en etkin iletişim aracı sayılmaktadır. Aynı şekilde takip edilen gelişmeleri seyirciye canlı olarak takip etme imkânı sunduğundan dolayı, buradan verilen mesajların daha kalıcı ve etkilidir. Yapılan araştırmalara göre, insanların televizyon karşısında geçirdikleri vakit günlük ortalama beş

\footnotetext{
${ }^{36}$ İman Abdulrahman Ahmed Mahmud, a.g.e., s. 55.

${ }^{37}$ İman Abdulrahman Ahmed Mahmud, a.g.e., s. 49.
} 
saatten fazladır. ${ }^{38}$ Ayrıca televizyon ekranlarında izlenen programların içeriğine gösterilen ilginin ve dolayısıyla insanların üzerindeki etkisinin diğer tüm medya araçlarından daha fazla olduğu söylenebilir.

$\mathrm{Bu}$ denli etkili ve kapsamlı olan televizyonların, güvenlik medyası kapsamında kullanılması kaçınılmazdır. Zira iletilmek istenilen mesajın etki yarattığı aşikârdır. $\mathrm{Bu}$ kapsamda, toplumun güvenlik bilincini artırmak için televizyonlar aracıllğıyla farklı programlar düzenlenebilir. $\mathrm{Bu}$ programlar çerçevesinde, kişiler güvenliğin sağlanmasında bireyin sorumluluğu ve güvenliğin toplum ve bireyler için önemi hakkında bilinçlendirilerek güvenliğin sağlanmasında katkıda bulunulabilir. Ayrıca, ülkenin ulusal ve uluslararası güvenlikle ilgili belirlenen uzun vadeli planşar ve stratejiler çerçevesinde film, program, belgesel ve dizi gibi faaliyetler düzenlenebilir. Zira günümüzde Hollywood'a baktığımızda, bu yönde birçok dizi ve film olduğu görülecektir.

Televizyon ve güvenlik medyası konusunu irdeledikten sonra, çalışmanın bir sonraki başlığında günümüzde en çok kullanılan medya araçlarından internet ve güvenlik medyası arasındaki ilişki üzerinde durulacaktır.

\section{4. İnternet ve Sosyal İletişim Araçları}

İnternet günümüzde bilgiye ulaşmada en hızlı, yaygın ve elverişli bir araçtır. Bir kişi oturduğu yerden her konuda istediği miktar ve nitelikte bilgi sahibi olabilir. Küreselleşmenin ve teknolojik gelişmelerin bir sonucu olarak, internet, insanlar arasındaki iletişimi de kolaylaştırmaktadır. Dünyanın farklı kıtalarında olan kişi veya kişiler birbirleriyle anlık iletişim kurabilir ve istedikleri konular hakkında fikir alışverişi yapabilir; bilgi aktarabilir ve bu kapsamda birbirlerinden etkilenebilir. Ayrıca, kişiler günümüzde yaygın biçimde kullanılan Facebook, Twitter ve WhatsApp gibi sosyal iletişim araçlarıyla fikir ve tecrübelerini paylaşabilir.

\footnotetext{
${ }^{38}$ Abdulrahman Bin Mohammed Asiri, a.g.e., s. 24.
} 
138

Güvenlik

Stratejileri

Y1l: 13

Sayı: 26

$\mathrm{Bu}$ konuda güvenlik medyasının verimli kullanmakta olduğu araçlardan biri, internet ve sosyal iletişim araçlarıdır. Oluşturulacak internet sitesi ve hesaplar aracılığıyla dünyanın her yerine bilgi ulaştırılabilir ve geniş bir hedef kitlesinde etki yaratılabilir. Nitekim günümüzde uyuşturucuyla mücadele kapsamında oluşturulan birçok site, sayfa ve elektronik platform mevcuttur. Ayrıca, güvenlik birimleri ve vatandaşlar arasındaki koordinasyon ve iş birliğini güçlendirme kapsamında elektronik olarak bilgi alışverişi ve iletişim imkânını sağlayan birçok yöntem vardır. Sahip olduğu geniş kullanıcı kitlesi ve bilgiyi ulaştırma/ulaşma konusunda hızından dolayı internet ve sosyal iletişim araçları güvenlik medyası için önemli bir araçtır. Farklı yöntemler kullanarak bu alanda verimli sonuçlar elde edilebileceği düşünülmektedir.

Çalışmanın bir sonraki başlığında günümüzde yaygın olarak kullanılan diğer iletişim aracı olan telefonun güvenlik medyasındaki rolü ve önemi tartış1lacaktır. Ayrıca günümüzde Türkiye gibi bazı ülkelerde güvenlik medyası ile arama operatörleri arasında ülkenin ulusal güvenliği çerçevesinde yapılan koordinasyon ve iş birliği kapsamında vatandaşlara farklı güvenlik konularına ilişkin olarak atılan ve "önleyici güvenlik mesajları" olarak adlandırabileceğimiz mesajlar bulunmaktadır. Çalışmanın bu kısmında söz konusu mesajlardan bazılarına örnek olarak çalışmada yer verilecektir.

\subsection{Arama Operatörleri}

Cep telefonları, iletişim konusunda günümüzde kullanılan en yaygın araçlardandır. Zira bugün cep telefonu kullanma yaşının 10 yaşına kadar düştüğü bilinmektedir. Bazen bir kişinin birden fazla telefon kullandığı durumlar karşımıza çıkmaktadır. İnsanların birebir olarak iletişim kurup bilgi alışverişi yaptığı telefonlar, güvenlik medyası için önemli bir araçtır. $\mathrm{Bu}$ denli yaygın kullanılan cep telefonları, bilgiyi ulaştırma konusunda kullanılmaya da elverişlidir. $\mathrm{Bu}$ anlamda, güvenlik medyasının birimleri ile ülkede mevcut olan telefon operatörleri arasında kurulacak iş birliği ve koordinasyon platformu büyük önem arz etmektedir. Nitekim bugün Türkiye'de olduğu gibi, birçok ülkede de bu gibi bir iş birliği ve koordinasyon söz konusudur. 
Küreselleşme Asrında Ulusal Güvenlik Perspektifinden

Medya-Güvenlik İlişkisi ve Topluma Yansımaları

Bugün farklı yöntemlerle arama operatörleri ülkenin ve toplumun güvenliğine katkı sağlamaktadır. $\mathrm{Bu}$ yöntemlerden biri, güvenlik medyasının birimleri ile yapılan koordinasyon neticesinde gerçekleştirilen kısa mesaj yöntemidir. Yukarıda ifade edildiği üzere, "önleyici güvenlik mesajları" olarak adlandırabileceğimiz bu mesajlar, toplumu güvenlikle ilgili hususlarda bilgilendirmekte ve dolayısıyla güvenliğin sağlanmasında büyük rol oynamaktadır. Farklı dönemlerde belirli sorunlara hitap edecek şekilde düzenlenebilecek bu mesajlar, güvenliğin sağlanmasındaki rolünün yanı sıra, hem güvenlik birimleri hakkında vatandaş nezdinde olumlu izlenim oluşturacak, hem de insanları yeni suç yöntemleri hakkında aydınlatacaktır. Bu mesajlara örnek olarak Türk Polis Teşkilatı'nın ve Jandarma Genel Komutanlığı'nın uygulamaları örnek alınabilir.

Türk Polis Teşkilatı ve Jandarma Genel Komutanlığı, ülkede hizmet sunan telefon operatörleriyle yapılan koordinasyon soncunda farklı dönemlerde meydana gelen veya gelebilecek suçlarla veya tehlikelerle ilgili vatandaşları kısa mesaj yöntemiyle bilgilendirmektedir. Gönderenin polis veya jandarma olarak belirlendiği bu mesajlar, uyarı niteliğinde olabileceği gibi, hatırlatma veya bilgilendirme şeklinde olabilir. Örneğin bayram veya tatil dönemlerinde sürücülere süratli araç kullanmanın sonuçları hakkında hatırlatma niteliğinde bir mesaj gönderilmektedir. Ayrıca, gelişen suç türleri hakkında vatandaşlara yapılan hatırlatmada da aynı yöntemin kullanıldığını bilinmektedir. Söz konusu mesajlardan örnek vermek verirsek:

"GÖNDEREN POLIS: Telefonda kendisini polis, savcı, asker olarak tanıtıp, 'adınız darbeye karıştı', 'adınız darbeciler listesinde' diyerek para ve altın isteyenlere inanmayın. www.asayis.pol.tr".

$\mathrm{Bu}$ önleyici kısa güvenlik mesajı, suçların gelişen genel şartlara paralel olarak geliştiğini göstermektedir. Zira mesaj1 15 Temmuz 2016 tarihinde, ülkenin birliği ve demokrasisini hedef alan FETÖ tarafindan girişilen menfur darbe girişiminden hemen sonra yeni çıkan suç türü hakkında vatandaşlara uyarı niteliğindedir. Mesajda görüldüğü üzere suçlular toplumdaki gelişmeleri istismar ederek farklı kisvelere bürünüp yeni bir dolandırıcılık yöntemini ortaya çıkartmışlardır. $\mathrm{Bu}$ 
mesajın, aynı zamanda polis teşkilatıyla ilgili olarak vatandaşlar nezdinde olumlu izlenim bırakması beklenmektedir. Diğer örnek şöyledir:

"Gideceğiniz yere erken ulaşmaya çalışmak, hiç ulaşamama riskini almak demektir. Can güvenliğiniz için yasal hız limitlerini aşmayınız. Emniyet Genel Müdürlüğü, Trafik Hizmetleri Başkanlı̆̆ı"”.

$\mathrm{Bu}$ mesajda ise bayram veya tatil dönemlerinde trafik güvenliği kapsamında vatandaşlar süratli araba kullanmanın tehlikeleri ve sonuçları ile ilgili uyarılmaktadır. Böylece hem yasal hızın üstünde araba kullanmadan meydana gelebilecek tehlikelerin önüne geçilebilecek, hem de güvenlik birimleri ile vatandaşlar arasındaki bağlar güçlenecektir. Son örnek ise şöyle verilebilir:

"Kaytp Buse A. 13 yass, 1.65 boy, 60 kg, esmer tenli, üzerinde siyah pantolon, siyah beyaz kareli gömlek, spor ayakkabı mevcut. Detay için www.asayis.pol.tr/k/335.jpg"

Görüldüğü üzere, bu mesaj, güvenliği sağlamak konusunda toplumda herkesin sorumlu olduğu anlayışını pekiştirmektedir. Nitekim bu mesajla kaybolan bir vatandaşın bulunmasında vatandaşların katkısı sağlanmaktadır.

Başlığın ilk kısımlarında konu ile ilgili genel bilgiler ve mesaj örnekleri verilmiştir. Bundan sonraki çalışmanın başlığında medya ile güvenlik birimleri arasındaki iş birliği irdelenecektir.

\section{Medya ile Güvenlik Kurumları Arasındaki İş Birliği ve Koordinasyon}

Güvenlik ile medya arasındaki etki karşılıklıdır. Medyanın toplum üzerinde pozitif veya negatif etkisi olduğu aşikârdır. Aynı şekilde medya organlarında ele alınan konuların içerikleri ve sunuş biçimleri, güvenliğin sağlanmasını pozitif yönde etkileyebileceği gibi, negatif yönde de etkileyebilir. Bu durum medya organlarının tutumu ve toplumun güvenlik konusundaki bilinç seviyesine bağlidır. Diğer taraftan, güvenlik birimlerinin görevlerini yapmaması halinde toplumun güvenliği sarsılır. Böyle bir durumda ise, medya başta olmak üzere toplumu oluşturan tüm kurum ve sektörler işlemez hâle gelir. 
Küreselleşme Asrında Ulusal Güvenlik Perspektifinden

Medya-Güvenlik İlişkisi ve Topluma Yansımaları

Başka bir ifadeyle, güvenliğin olmadığı bir toplumda hayatın normal akışından bahsetmek mümkün değildir. $\mathrm{Bu}$ çerçevede, medya ile güvenlik birimleri arasındaki iş birliğinin elzem olduğu ifade edilebilir.

Nitekim güvenlik birimleri ve medya arasındaki iş birliğinin söz Güvenlik Stratejileri Y11: 13 konusu olamadığı durumda, ne güvenlik birimleri görevlerini tam anlamıyla başarabilir, ne de medya görevini yapabilir. Güvenlik birimlerinin medyadan sakınması ve medyanın da güvenlik birimlerinden çekinmesi halinde, her iki sektörde olumsuz sonuçlar yaşanabilir. $\mathrm{Bu}$ nedenle, iki sektör arasındaki gerçekleştirilecek bir koordinasyon ve iş birliği kaçınılmazdır. ${ }^{39}$ Aslında günümüzün göz ardı edilemez gereksinimlerinden biri olan medya ile koordinasyon, diğer kurumlar için de geçerlidir. Zira medya ile koordinasyon içinde olmayan yahut bunun gerekli olduğunu düşünmeyen bir kurumun veya sektörün başarılı olmasının ve amaçlarına tam anlamıyla ulaşmasının neredeyse imkânsız olduğu söylenebilir.

Diğer açıdan bakıldığında, belirtildiği üzere güvenliğin söz konusu olmadığı bir ülkede kalkınmadan bahsedilemeyeceği gibi, tüm çalışma sistemlerinin işleyemez hâle geleceği de bir gerçektir. Bu nedenle, güvenlik ile medya arasındaki ilişkinin yakınlığının günümüz gereksinimlerinden biri olduğunu söylemek mümkündür. İki sektör arasında yapılacak koordinasyon ve iş birliği, bir bütün olarak ülkenin güvenliği için hayati önem teşkil etmektedir. Lakin burada güvenlik birimleri açısından belirtilmesi gereken önemli husus, söz konusu iş birliğinin ve koordinasyonun sadece geleneksel medya araçlarıyla sınırlı kalmaması gerektiğidir. Geleneksel medya araçlarının yanı sıra, gerekli durumlarda Facebook, Twitter, YouTube ve benzeri diğer elektronik medya araçları da kullanmalıdır.

Çalışmanın bir sonraki başlığında medyanın güvenlik konularına bakışı ve ele alma biçimlerinin toplum nezdindeki güvenlik birimleri ve personelleri hakkında oluşacak alg1 üzerindeki etkisi irdelenecektir.

\footnotetext{
${ }^{39}$ Fahad Abdulaziz Hamad Al-Deaij, Al-Amn va Al-íelam Fi Al-Duwal Al-íslamiya, 6. Bask1, Akadimiyet Naif Al-Arabiya Lil-Olum Al-Amniya, Riyadh, 1986, s. 249.
} 
142

Güvenlik Stratejileri

Y11: 13

Say1: 26

\subsection{Güvenlik Personelleri Hakkında Oluşan Algı}

Suçların sınır tanımaz olduğu küreselleşen çağımızda güvenlik birimlerinin görevi gittikçe genişlemektedir. Kişilere karşı meydana gelen herhangi bir tehlike söz konusu olduğunda, ilk önce güvenlik güçlerine ihtiyaç duyulmaktadır. Bu ise güvenlik güçlerinin zaman ve mekân tanımadan her zaman ve her yerde görev başında olmalarını gerekli kılmaktadır. Güvenliği sağlamak da bunu gerektirmektedir. İnsanlarla bu denli iç içe olan güvenlik güçlerinin bu anlamda topluma karşı sorumluluğunda başarılı olabilmesi için vatandaşların iș birliğine gereksinim duyulmaktadır. ${ }^{40}$ Söz konusu gereksinimin vatandaşlar tarafindan verilebilmesi için güvenlik güçlerinin toplum nezdinde iyi izlenime sahip olması gerekmektedir.

Böyle bir imaj ve izlenimin söz konusu olabilmesinde medyaya büyük görev düşmektedir. Medyanın güvenlik birimlerinin önemini ve toplumda yaşanan güvenlik sorunlarının ortadan kaldırılmasında güvenlik birimlerinin gösterdiği çabayı ele alış biçimi bu anlamda etkilidir. Medyanın, güvenlik personeli hakkında topluma sunacağ 1 içerikler, yıpratmaya ve toplum nezdinde olumsuz imaj oluşturmaya yönelik olursa, insanların güvenlik personeline güveni sarsılır ve iş birliği konusunda istenilmeyen olgular ortaya çıkabilir. ${ }^{41} \mathrm{Bu}$ durum da ülkenin güvenliğinde olumsuzluklara yol açacaktır.

Diğer taraftan, güvenlik birimleri, yaşanan olumsuzluklara göz yummadan vatandaşları bu konuda bilgilendirmelidir. Yapılan yanlışlar açıklanmalı ve sorumlulara gereken yaptırımları uygulamak için çaba gösterilmelidir. Lakin bu çerçevede dikkat edilmesi gereken bir ayrıntı, münferit olayların genellememesidir. Bazen medya organlarında güvenlik birimleriyle ilgili konular ele alınırken, bu birimlerde görev yapan personel toplumun bir parçası olarak değil de, ayrı bir toplumun

${ }^{40}$ Baraka Bin Zamil Al-Hawshan, a.g.e., s. 37.

${ }^{41}$ Abdullaah Bin Ayt Al- Shahri, Al-Tajamhur Va Inikasataho Ala Ada Ajhizat AlAnm va Al-Salama, Markaz Al-Buhoos va Al-Dirasat, Naif University for Security Sciences. Riyadh, 2012, s. 37. 
Küreselleşme Asrında Ulusal Güvenlik Perspektifinden

Medya-Güvenlik İlişkisi ve Topluma Yansımaları

bireyleri olarak gösterilir. Oysa güvenlik birimlerinde çalışan her personel, toplumun bir parçasıdır ve toplumda yaşanan her olumsuzluklardan doğrudan etkilenir. Bu nedenle, medyanın bu konuları ele alırken hassas ve dürüst davranması gerekir. Aksi takdirde, toplumda ayrışmalar, kutuplaşmalar ve en önemlisi güvenlik sorunları yaşanacaktır.

Çalışmanın bir sonraki başlığında medya ve toplumdaki suç oranı arasındaki bağlantının üzerinde durulacaktır.

\subsection{Toplumda Suç Oranının Azaltılmasında Medyanın Rolü}

Suçun bir toplumsal davranış olarak toplumda tamamen engellenmesi imkânsızdır. Ancak farklı yöntemlerle azaltılabilir. Bu yöntemler arasında, güvenlik birimlerinin bu alanda gösterdiği çabaların yanı sıra, medyanın bu konuda oynadığı rol de vardır. ${ }^{42}$ Medya insanların hayatlarını şekillendirmede ve insanları yönlendirmede önemli bir etkiye sahiptir. Zira günümüzde insanlar adeta televizyon ekranlarında gördüklerine fazlasıyla özenerek o şekilde yaşama ve davranmaya çalışmaktadır. Ayrıca, hayata dair yorumları da bu çerçevede şekillenmektedir. İnsanların davranışlarının ve kişiliklerinin şekillenmesinde bu denli etkili olan medyanın toplumda suçun ve istenilmeyen davranışların engellenmesinde de bir rolü olacağı aşikârdır.

$\mathrm{Bu}$ çerçevede, güvenlik medyası kapsamında alınacak tedbirlerin önemi ön plana çıkmaktadır. Zira güvenlik medyası, medyanın farklı alan ve organlariyla kuracağı koordinasyon dâhilinde toplumun gelenek ve kültürel yapılarına göre toplumsal ve bireysel perspektifinden tehdit teşkil edecek içeriklerin engellemeyi amaçlamaktadır. ${ }^{43}$ Özellikle toplumsal ve bireysel güvenliği tehdit eden suçlar, nefret suçları, şiddet ve asayiş olayları bu konuda önem taşımaktadır. Nitekim bugün medya programlarının içerdiği şiddet vakaları, insanların çocuk yaştan başlayarak şiddet ve nefrete başvurmasına neden olmaktadır. Diğer

\footnotetext{
${ }^{42}$ Abdullah Bin Saoud Al-Sarani, "Dawr Al-İlam Al-Amni Fi Al-Wikhaya Min AlJarima", Al-Jahani, Ali Bin Fayiz (ed.), Baramij A-Lilam Al-Amni Beyn Al-Wakhi va Altataloat, Manshorat Naif University for Security Sciences, Riyadh, 2012, 45-89, s. 47.

${ }^{43}$ Ali Bin Fayiz, Al-Jahani, 2000, a.g.e, s. 219.
}

Güvenlik Stratejileri

Y11: 13

Say1: 26 
144

Güvenlik

Stratejileri

Y1l: 13

Say1: 26 açıdan, medyanın ele alacağı konularla ve farklı faaliyetler çerçevesinde göstereceği önleyici güvenlik programlarıyla insanların toplumu tehdit eden herhangi bir eyleme teşebbüs etmesi engellenmektedir.

Görüldüğü üzere, medya toplumda suç oranının azalmasına neden olabileceği gibi, olumsuz içeriklerle toplumda suç işlemek için elverişli ortamın oluşmasına da neden olabilir. Burada ise medya organlarının bilinç ve farkındalığı ile güvenlik ve diğer ilgili birimler arasında kurulacak koordinasyon ve iş birliğinin büyük rolü vardır. Burada ifade edilmesi gereken önemli husus, günümüzde medyanın durumunun bu koordinasyonu ve iş birliğini zorlaştırdığıdır. Nitekim medya bugün, bir ekonomi ve çıkar sektörü olmasının yanı sıra, çok farklı araçlarla kontrolsüz bir şekilde genişlemeye devam etmektedir.

Medyanın suç ve suçluluktaki etkisini irdeledikten sonra çalışmanın bir sonraki başlı̆̆ında konunun ülkenin ulusal güvenliğine etkisi tartışılacaktır.

\section{Güvenlik Medyası ve Ulusal Güvenlik}

Ulusal güvenlik kavramı, güvenlik kavramı gibi, gelişmelere paralel olarak sürekli olarak değişen bir kavramdır. Zira daha önce devlet-ulus kavramları döneminin önemli değerleri olduğundan o dönemde ulusal güvenlikle ilgili tanımların çoğu, kavramın devlet güvenliği sağlamaya ilişkin tehlike ve tehditleri ifade edecek şekilde tasarlanmıştır. Lakin bugün ulusal güvenliğe yapılan tüm tanımların odağında, insani güvenlikle birlikte, ülke içinde barınan tüm aktörlerin güvenliği yer almaktadır; çünkü günümüzde en önde gelen değerler, bireyin hak ve özgürlükleri ile demokratik değerlerdir. ${ }^{44}$

Fakat ulusal güvenlik kavramı, her ne kadar bir dönüşüm süreci içine girerek ilk ortaya çıktığ 1 dönemdeki anlamlarının dışında farklı anlamlar ifade edecek şekilde genişlese de, henüz insanların zihinlerinde yeni anlamıyla tam olarak yerleşememiştir. Nitekim günümüzde ulusal güvenlik denildiğinde, bu kavram çoğunlukla devletle ve ulusla

${ }^{44}$ Fatih Beren, Demokrasi ve Özgürlüğ̈̈̈n Teminatı Olarak Içc Güvenlik İstihbaratı, Alfa Yayınları, İstanbul, 2010, s. 38. 
Küreselleşme Asrında Ulusal Güvenlik Perspektifinden

Medya-Güvenlik İlişkisi ve Topluma Yansımaları

ilişkilendirilmektedir. Oysa bugün toplumda herhangi bir güvenlik 145 tehdidi doğrudan ulusal güvenliğe etki etmektedir; çünkü bir ülkede güvenliğin sağlanması bir bütündür. Herhangi bir kısım ve alan güvenlik tehdidi altındaysa, söz konusu toplumda tam anlamıla bir güvenlikten bahsetmek anlamsız olacaktır. Bununla birlikte, güvenlik alanında yapılan bazı bilimsel çalışmalarda ulusal güvenlik kavramının iç güvenliğin yanı sıra dış güvenliği de kapsadığ 1 öne sürülmüştür. ${ }^{45}$

Aslında günümüzün gelişen şartları altında ülkenin iç güvenliğini dış güvenliğinden bağımsız düşünmek bir eksikliktir; çünkü aynı ülkenin sınırları içinde yaşanan tüm olumsuzlukların, iç mekanizmalara etki edeceği gibi, uluslararası arenada da etkili olacağı düşünülmektedir. Öyle ki, bugün iç ve dış güvenlik kavramlarını birbirleriyle bağlantılı olarak ifade eden "Intermestic Security", kavramı, güvenlik çalışmalarının odağına hızla oturmaya başlamıştır. ${ }^{47}$ Toplumun barındırdığı her kesime yönelik tehdit ve tehlikelerden doğrudan etkilenen ulusal güvenlik kavramının, toplumun güvenliğini tehdit eden tüm faktörlerden arındırmaya çalışan güvenlik medyasından etkilenmemesi beklenemez. Zira güvenlik medyasının mekanizmasının var olmamasından meydana gelebilecek tüm sorunlar ülkenin ulusal güvenliğini doğrudan etkilemektedir. ${ }^{48}$ Diğer bir açıdan bakıldığında, güvenlik medyasının programlarıyla güvenliği tehdit eden olguların engellenmesinin ülkenin ulusal güvenliğine olumlu etkiler bırakacağı düşünülmektedir.

Görüldüğü üzere, medya ile ulusal güvenlik arasında doğrudan bir etkileşim söz konusudur. Bu etkileşim olumlu veya olumsuz olabilir. Etkileşimin olumlu veya olumsuz olması, güvenlik medyasının

\footnotetext{
${ }^{45}$ Ömer Urhal, Küreselleșen Dünyada Güvenlik "Milli Güvenlik, Kamu Güvenliği, Örgütlü Suçlar ve Suç İstihbarat”, 2. Bask1, Adalet Yayınevi, Ankara, 2009, s. 68. 46 "Intermestic Security" Kavramı ülkenin iç ve dış güvenliğinin birbiriyle bağlantılı olmasını ifade eden bir kavramdır. International (uluslararası) ve Domestic (iç) sözcüklerinin birleşmesiyle meydana gelmiştir. "International" sözcügü, ülkenin dış güvenliğini, "domestic" sözcügü ise ülkenin iç güvenliğini ifade etmektedir.

${ }^{47}$ Bilal Karabulut, a.g.e. s. 117.

${ }^{48}$ Ziyab Musa Al-Bidaniya, AL-Amn Al-Watani Fi Asr Alawlama, Naif University for Security Sciences, Riyadh, 2011, s. 155.
}

Güvenlik Stratejileri

Y11: 13

Sayı: 26 
146

Güvenlik

Stratejileri

Y1l: 13

Sayı: 26

toplumda işlev görüp görmemesine bağlıdır. Çalışmanın bu bölümünde ulusal güvenlik ile medya arasındaki etkileşim irdelenmiştir. Çalışmanın sonuna gelinirken bir sonraki kısımda sonuç bölümüne yer verilecektir. Daha sonra ise geniş İngilizce özet çalışma ve sırasında başvurulan kaynaklar ayrıntılı olarak kaynakça kısmında yer alacaktır.

\section{Sonuç ve Öneriler}

Küreselleşmenin getirdiği imkânlarla birlikte, medyanın etkinliği arttığı gibi kapsamı da genişlemiştir. Öyle ki spor medyası, finans medyası ve güvenlik medyas 1 gibi farklı medya alanları ortaya çıkmıştır. Ayrıca, insanların üzerindeki etkinliği de daha önce benzeri olmayan biçimde artmıştır. Zira bugün medya, sınır tanımaksızın insanların hayatının her alanına girmeyi başararak adeta insanların birçok konuda nasıl düşüneceğini belirlemektedir. Bununla paralel olarak, güvenliğin kapsamı ve güvenliği sağlama yöntem ve stratejilerinde köklü değişimler yaşanmıştır. $\mathrm{Bu}$ doğrultuda, güvenlik ile medya arasında doğrudan bir bağlantının söz konusu olduğunu ifade etmek mümkündür. Nitekim günümüzde "güvenlik medyası" olarak adlandırılan kavram, medya ile güvenlik arasındaki koordinasyonu, iş birliğini ve etkileşimi ifade etmektedir.

Medya organlarının sorunsuz olarak çalışması için toplumda güvenliğin olması elzemdir; çünkü güvenliğin olmadığı bir toplumda hiçbir sektörün işlev görmesi beklenmemektedir. Aynı şekilde güvenlik birimlerinin toplumda güvenliği sağlaması için medyanın etki ve önemi göz ardı edilmemelidir. Nitekim medyanın insanlar üzerinde bu denli etkili olduğu çağımızda medyanın desteğini almadan başarılı olmak güçtür. Bu durum özellikle toplumun tamamını ilgilendiren konular için de geçerlidir. Diğer taraftan, güvenlik birimleri güvenliği sağlamada vatandaşların desteğini almadan başarılı olmayacağından, toplumun bu konuda bilinçlendirilmesi büyük önem arz etmektedir. Zira güvenlik konularına ilişkin bilinçli bir toplumun gerektiğinde güvenlik birimlerine destek verme konusunda tereddüt etmeyeceği düşünülmektedir. Aksi takdirde, toplum güvenlik birimlerine karşı olumsuz bir tutum sergileyecektir.

$\mathrm{Bu}$ doğrultuda, güvenlik birimleri ile medya arasında bahse konu iş birliğini ve koordinasyonu güçlendirecek faaliyetler yürütülmelidir. 
Küreselleşme Asrında Ulusal Güvenlik Perspektifinden

Medya-Güvenlik İlişkisi ve Topluma Yansımaları

Günümüzün güvenlik sorunlarıyla daha etkin bir mücadele yürütmek için güvenlik medyası geliştirilmelidir. Güvenlik birimleriyle medya arasındaki iş birliği kapsamında, güncel güvenlik sorunlarına hitap eden programlar üretilmelidir. Özellikle, çocuk programları güvenlik hissini güçlendirmeye yönelik olmalıdır. Zira küçük yaşta güvenliğin öneminin farkında olan bir kişinin hayatının ilerleyen aşamalarında bu konuda diğerlerinden daha bilinçli olacağı beklenebilir. Daha verimli ve sağlıklı iş birliği atmosferi oluşturmak için medya ile güvenlik birimleri arasında ortak çalışma grupları oluşturulmalıdır. Ayrıca, belirli aralıklarla bahse konu olan alanla ilgili bilimsel sempozyum ve seminerler düzenlenmelidir.

Bunun yanı sıra, medya sektöründe çalışanlar, güvenliğin önemi ve medyanın bu konudaki rolü ve etkisi hakkında eğitilmelidir. Aynı şekilde güvenlik birimleri yapılanması içinde güvenlik medyasıyla ilgili birimlerde çalışan personelin medyanın önemi ve güvenliği sağlama konusundaki rolü ile ilgili eğitilmesi önem arz etmektedir. Ayrıca, güvenlik medyasının birimleriyle medya organları arasında kurulacak güçlü iş birliği ve koordinasyon kapsamında hazırlanacak önleyici güvenlik programları çerçevesinde güvenliği sağlamakta sadece güvenlik birimlerinin değil; herkesin bir rolü olduğu düşüncesi pekiştirilmelidir.

\section{Summary}

In this study, we have tried to examine the interaction between security and media in our globalizing world. Indeed, the security phenomenon, which has a great importance for mankind from past to today, has experienced fundamental changes in its scope and concept along with the globalization. Parallel to these changes, the strategies, as well as the methods, to provide security have also changed. Not only the security units but also the individuals who share the community and other actors have a role in non-negligible degree in providing security in the society. One of these actors is the media. The media has a particularly great impact in the field of preventive security. Because media has a great impact for providing security, it necessitates establishing

Güvenlik Stratejileri

Y11: 13

Say1: 26 
148

Güvenlik

Stratejileri

Y11: 13

Say1: 26

corporation and coordination between these two sectors. Today, we see that "security media" concept is used from time to time in order to express the cooperation in question between media and security.

In this direction, the main subject of this study is designed to explain the nature of the "security media" concept and how the media plays a role in providing the security. In addition, the awareness level of the society with regards to security and the impact of media on this issue are evaluated in this study. The tools and methods of security media and their impact on the society are discussed as well. Within this framework, "preventive security messages" method, which is one of the methods used by the Turkish Police Department, is taken as an example and its impact on society is evaluated.

One of the results obtained within this scope is as follows: security media is one of inevitable facts in the security field today, although there is a perceivable deficiency in the scientific literature. Security cannot be provided by only security units under today's changing conditions, as it has been mentioned before. All parts of society have an important role in this field. The society must have awareness at a certain level to perform its role in this subject. The security media has an inevitable role to ensure that society reaches the awareness level in question. In this study, it is aimed to examine the importance and role of the security media comprehensively. 
Küreselleşme Asrında Ulusal Güvenlik Perspektifinden

Medya-Güvenlik İlişkisi ve Topluma Yansımaları

Kaynakça

Kitaplar ve Kitap Bölümleri

ABDULMAWLA, Sayd Shorbaci, Tasir Al-Carima Ala Kutat AlTanmiya Al-İctimaiya, Dar Al-Nashr Bil Markaz Al-Arabi Lil-Dirasat Al-Amnniya ve Al-Tadrib. Riyadh, 1994.

AL-ASFAR, Ahmed Abdülaziz, Asbab Taati Al-Mukhatdirat Fi AlMojtama Al-Arabi, Markaz Al-Buhoos va Al-Dirasat, Naif University for Security Sciences, Riyadh, 2012.

AL-BIDANIYA, Ziyab Musa, AL-Amn Al-Watani Fi Asr Alawlama, Naif University for Security Sciences. Riyadh, 2011.

AL-DEAİJ, Fahad Abdulaziz Hamad, Al-Amn va Al-íelam Fi AlDuwal Al-İslamiya, 6. Bask1, Akadimiyet Naif Al-Arabiya Lil-Olum Al-Amniya. Riyadh, 1986.

AL-HAWSHAN, Baraka Bin Zamil, Al-Eilam Al- Amnni va Al-Amn ALEilami, Naif University for Security Sciences Yayınları. Riyadh, 2004.

AL-JAHANI, Ali Bin Fayiz, (ed.), "Al-İlam Al-Amni Beyn Al-Wakhi va Al-Tataloat", Al-Jahani, Ali Bin Fayiz, Baramij A-Lilam Al-Amni Beyn Al-Wakhi va At-Tataloat, Manshorat Naif University for Security Sciences, Riyadh, 2012.

AL-JAHANI, Ali Bin Fayiz, Al-İelam Al-Amni va Al-Wikhaya Min Al-Jarima, Markaz Al-Buhoos va Al-Dirasat, Naif University for Security Sciences, Riyadh 2000.

AL-RIBAYA Ahmed, Asar Al-Sakhafa Va Al-Mujtama Fi Daf AlFard Ila Irtikan Al-Jarima, Al-Markaz Al-Arabi Lildirasat AlAmniya va Al- Tadrib, Riyadh, 1984.

AL-SARANI, Abdullah Bin Saoud, (ed.), "Dawr Al-İlam Al-Amni Fi Al-Wikhaya Min Al-Jarima", Al-Jahani, Ali Bin Fayiz Baramij ALilam Al-Amni Beyn Al-Wakhi va Altataloat, Manshorat Naif University for Security Sciences, Riyadh, 2012.

AL-SHAHRANY, Saeed Bin Ali, Idarat Amaliyat Al-Azmaat AlAmniya, Naif University for Security Sciences. Riyadh, 2005.

AL- SHAHRİ, Abdullaah Bin Ayt, Al-Tajamhur Va İnikasataho Ala Ada Ajhizat Al-Anm va Al-Salama, Markaz Al-Buhoos va Al-Dirasat, Naif University for Security Sciences, Riyad, 2012. 
AL-SHAMMASI, İbrahim Bin Ahmed, (ed.), "Al-Sakhafa AlAmniya", Al-Khamdi Abdülaziz Al-İlam va Asaraho Fi Al-Wikhaya Min Al-Jarima Beyn Al-Ijab Va Al-Salb, Manshorat Naif University for Security Sciences, Riyadh, 2003. AL-SHINKHETI, Saeed Mohammed Sadati, Mafahim İslamiya Min Al-Khuran Al-Karem, Dar Alam Al-Kitab, Riyadh, 1986.

AL-ZİBIN, İbrahim Mohammed, "Al-Asar Al-İktisadiya Al-Natija An Zahirat Al-Nashl", Al-Tarawna Mohamed (ed.), Zahirat Al-Nashl va Asariha Al-Ijtimaiya, Manshorat Naif University for Security Sciences, Riyadh, 2009.

ASİRI, Abdulrahman Bin Mohammed, "Maham Al-İlam Al-Amni va vazaifaho Fi Al-Mujtamaat Al-Arabiya Al-Muasira", Khaddoor, Adeeb (ed.), Al-illam va Al-Amn, Markaz Al-Buhoos va Al-Dirasat, Naif University for Security Sciences, Riyadh, 2006.

BEREN, Fatih, Demokrasi ve Ö̈zgürlüğ̈̈n Teminatı Olarak İç Güvenlik İstihbaratı, Alfa Yayınları, İstanbul, 2010.

BEYTALMAL, Hamza Ahmed, "Dawr Al-İlam Alamni Fi AlWikhaya Min Al-Harima", Al-Jahani, Ali Bin Fayiz (ed.), Al-ílam AlAmni va Al-Azmat, Manshorat Naif University for Security Sciences, Riyadh, 2012.

BRAUCH, Günter Hans, "Uluslararası İlişkilerde Çatışmadan Güvenliğge", Mustafa Aydın (der.), Güvenliğin Yeniden Kavramsallaştırılması: Barış, Güvenlik, Kalkınma ve Çevre Kavramsal Dörtlüsü, İstanbul Bilgi Üniversitesi Yayınları, İstanbul, 2015.

HARIZ, Mohamed Al-Habib, "Wakhai Al-amn Al-fikri", Al-Liwehakh Abdulrahman (ed.), Al-Amn Al-Fikri, Manshorat Naif University for Security Sciences, Riyadh, 2005.

KARABULUT, Bilal, Küreselleşme Sürecinde Güvenliği Yeniden Düşünmek, Barış Kitabevi, Ankara, 2011.

KHADDOOR, Adeeb, Al-illam Va Al-Amn, Naif University for Security Sciences, Riyadh, 1999.

MAHMUD, İman Abdulrahman Ahmed, Dawr Al-İaa Fi Nashr AlTawiya Al- Amnniya: Al-ízaa Al-Sudaniya Anmuzacan, Manshorat Naif University for Security Sciences. Riyadh, 2010. 
MENJI, Mohammed Abdulfattah, "Al-Takhtet Fi Majal Al-Amn", Murad Faruk (ed.), Al-Takhtyet Al-Amni, Markaz Al-Buhoos va AlDirasat, Naif University for Security Sciences. Riyadh, 1993.

TİAB, Tirab Abbkar, Çokkültürrlülük ve Güvenlik: Sudan Örneği, Güvenlik Stratejileri Sonçağ Yayınları, Ankara, 2016.

URHAL, Ömer, Küreselleşen Dünyada Güvenlik "Milli Güvenlik, Y11: 13

Kamu Güvenliğ̈i, Örgütlü Suçlar ve Suç İstihbaratı”, 2. Bask1, Adalet Yayınevi, Ankara, 2009.

YILDIRIM, Rahmi, "Dördüncü Ordu Medya", Karınca Yayınları, Ankara, 2010.

ZEDNER, Lucia, Güvenlik, çev. Defne Orhun, Optimist Yayın Grubu, İstanbul, 2015.

\section{Makaleler}

ARENDS, J. Frederik M., "Homeros'dan Hobbes ve Ötesine: "Güvenlik" Kavramının Avrupa Geleneğindeki Boyutları", Uluslararası İlişkiler, Cilt 6, Sayı 22, 2009.

BENJAMIN, Miller, "The Concept of Security: Should it Be Redefined" Journal of Strategic Studies, Vol. 24, No. 2, 2001.

İnternet Kaynakları

CORTES, Carlos E., Using Media To Support Multiculturalism, http://www.intime.uni.edu/multiculture/Media/media.htm (Erişim Tarihi: 07 Ekim 2010).

KELLNER, Douglas, Cultural Studies, Multiculturalism, and Media Culture, https://pages.gseis.ucla.edu/faculty/kellner/essays/culturalstudies multiculturalism.pdf (Erişim Tarihi: 06 Ekim 2015).

PETROZZA, Julia, Critical Multicultural Education and the Media, http://www.edchange.org/multicultural/papers/media.html (Erişim Tarihi: 06 Ekim 2015). 

